\title{
Ankara İlinde Yapılan Etnobotanik Çalışmaların, Covid-19 Pandemisi Üzerinde Değerlendirilmesi
}

\author{
Yelda AKILLIGÖZ ${ }^{1 *}$ (iD), Ahmet BAŞARAN ${ }^{2}$ \\ Başkent Üniversitesi, Eczacılık Fakültesi, Farmakognozi Anabilim Dalı, Ankara, Türkiye \\ *Sorumlu Yazar / Corresponding Author: Yelda AKILLIGÖZ, e-posta: yelosca@gmail.com
}

\section{ÖZET}

Dünya Sağlık Örgütü (DSÖ), 2019 yılında Covid-19 pandemisini ilan etti. Pandemi, yüksek oranda ölüme neden oldu. Koronavirüslere, özellikle SARS-CoV-2'ye karşı birçok aşı ve ilaç geliştirme çalışması halen devam etmektedir. Bitkiler, geleneksel tıpta, yüzyıllardır halk ilacı ve gıda olarak kullanılmaktadır. Bitkilerden elde edilen ekstraktlar ya da etken maddeler üzerinde sözü edilen virüslere karşı yapılan aktivite çalışmaları mevcuttur. Bu derlemede iki aşamalı araştırma yapılmıştır. İlk olarak, Ankara ilinin Altındağ-Bağlum-Kılıçlar; Beypazarı-Ayaş-Güdül, Çamlıdere, Çubuk Çay1-Tatlar arası, Güdül, Haymana, Polatlı (Avşar-Şabanözü- Çile Dağı) ve Yenimahalle-Kazan bölgelerinde yapılan etnobotanik çalışmalar sonunda yayımlanmış bitkiler taranmıştır. Daha sonra, kullanımları, Covid-19 belirtileriyle uygunluk gösteren türler tespit edilmiştir. Ayrıca antiviral çalışmalardan; RNA virüslerine karşı etkili olan türler belirlenmiştir. Bu derleme çalışmasında, etnobotanik çalışmalarda etkileri tespit edilen türler üzerinde antiviral aktivite çalışmalarının yapılarak; Covid-19'da kullanılmak üzere ilaç geliştirme çalışmalarında, tıbbi tedavide yer alabilmelerinin sağlanması amaçlanmaktadır.

Anahtar Kelimeler: Etnobotanik çalışmalar, Tıbbi bitkiler, Antiviral, Koronavirüs, Covid-19, SARS-CoV-2, Türkiye 


\title{
Evaluation of Ethnobotanical Studies Conducted in Ankara Province on Covid-19 Pandemic
}

\begin{abstract}
World Health Organization (WHO) proclaimed Covid-19 pandemic in 2019. The pandemic caused a high rate of death. Many vaccine and drug development studies still continue against coronaviruses, particularly on SARS-CoV-2. The plants have been used as folk medicine and food in traditional medicine for centuries. Antiviral activity studies are also studied on some plant extracts or their active compounds with the mentioned viruses. This review consists of 2 steps. First, at the end of ethnobotanical studies conducted in different districts of Ankara province, such as Altındağ-BağlumKılıçlar, Beypazarı-Ayaş-Güdül, Çamlıdere, Çubuk Stream- Tatlar, Güdül, Haymana, Polatlı (AvşarŞabanözü-Çile Mountain) and Yenimahalle-Kazan, published plants were scanned. Then, the species whose uses are consistent with Covid-19 symptoms were identified. In addition, species that are effective against RNA viruses have identified from antiviral activity studies. In this review study, By conducting antiviral activity studies on species whose effects have been identified in ethnobotanical studies; in drug development studies for use in Covid-19, it is aimed to ensure that they can participate in medical treatment.
\end{abstract}

Key words: Ethnobotanic studies, Medicinal plants, Antiviral, Coronavirus, Covid-19, SARS-CoV-2, Turkey

\section{GíRiş}

Etnobotanik terimi ilk defa 1896 yılında John W. Harshberger kullanmıştır (Robbins, 1916). Etnobotanik, insanlarla bitkiler arasındaki ilişkileri incelemektedir. Bu çalışmalar arasında bitkilerin, halk ilacı, gida, baharat, boyar madde, süs, tütsü, sabun olarak; ayrıca çeşitli aletlerin yapımında kullanımları ve/veya bitki türlerinin adlandırılmaları yer almaktadır. Çalışma sonunda bitkinin yöresel ad1, o bölgedeki kullanılma amacı, kullanılan kısmı, hazırlama şekli, toplanma şekli, nasıl yetiştirildiği, o bölgedeki anlamı veya kullanılmayan türler tespit edilmektedir. Ülkemizde halkın bitkilerle ilişkisi ilk defa 2002 yılında Türkiye Bilimler Akademisi tarafından listelenmiştir. Türkiye Kültür Sektörü (TÜBA-TÜKSEK) kapsamına etnobotanik çalışmalar da alınmıştır (Kendir, 2010; Kaya, 2011).

Dünya Sağlık Örgütü'nün, 2019 yılında Covid-19 pandemisini ilanıyla birlikte, bütün dünyada ilaç araştırmaları hız kazanmıştır (Yuen,
2020). Son dönemde Covid-19 pandemisinin tedavisinde kullanılan ilaçların etkinlikleri ve yan etkilerinde yaşanan sorunlar nedeniyle, etnobotanik çalışmalar tekrar gözden geçirilmeye başlanmış ve bitki ekstraktlarının, çeşitli çözücülerle elde edilen fraksiyonları ya da izole edilen etken maddeleri üzerinde antiviral aktivite araştırmaları yoğunlaşmıştır. Bu şekilde yapılan çalışmalardan elde edilen bulgular, ilaç araştırmaları için yapılacak bilimsel çalışmalara da yol göstermektedir (Patel, 2020).

Covid-19'da SARS-CoV-2 ile enfekte olmuş kişilerde, akut pnömoni, ateş, grip benzeri belirtiler, öksürük, baş ağrısı, kas ağrısı, nefes darlığ 1 yanında; kusma ve ishal gibi atipik belirtiler görülmektedir (Patel ve ark., 2020). Bu derleme çalışmasında, Covid-19'da kullanılmak üzere ilaç geliştirme çalışmalarında, bitkilerin de tıbbi tedavide yer alabilmelerinin sağlanması amaçlanmıştır. Bu amaçla, Ankara ilinin değişik bölgelerinde yapılan etnobotanik çalışmalar taranmış, ilgili bölgelerdeki kullanılışları, Covid- 
Journal of Integrative and Anatolian Medicine

Bütünleyici ve Anadolu Tıbbı Dergisi
Cilt/ Volume: 2 Sayı / Issue: 3 Yli/Year: 2021
Yayıncı / Publisher

Sağllk Bilimleri Üniversitesi University of Health Sciences
19 belirtileri ile uygunluk gösteren bitki türleri tespit edilmiştir. Ayrıca RNA virüsleri üzerinde bitkilerle yapılmış antiviral aktivite çalışmalarının yayınları incelenerek; etnobotanik çalışmalarda tespit edilen türlerin kullanılışları ile karşılaştırılmıştır. Antiviral aktivite tayininde etkili bulunan türler temel alınarak; aynı cinse ait farklı türler de tartışılmıştır.

\section{MATERYAL ve METOT}

Ankara ilinde yapılan etnobotanik çalışmalar ve RNA virüslere etkili bitki türlerinin taranmasi amaciyla, Google arama motorunda internet sitelerinden, kayitlı elektronik dergilerden ve kitaplardan, YÖK Ulusal Tez Merkezi' nde kayıtlı pdf formatındaki tezlerden, TÜBİTAK ULAKBİM Dergi Park'da kayitlı orijinal makale ve derlemelerden; ayrıca Dünya Sağlık Örgütü (WHO)'nün güncel bilgi ve kaynaklarından yararlanılmıştır.

Kaynak taraması sonrasinda, koronavirüslere ait genel bilgi ile birlikte, Ankara ili etnobotanik çalışma sonuçlarından, kullanımları Covid-19 belirtileriyle eşleşen bitki türlerine ait çalışmalar tablo ve metin halinde, bölgelere göre bitki türlerinin sayısı ve oranı ile kullanım alanına göre bitki türlerinin sayısı ve oranı tablolar halinde, bölgelere göre bitki türlerinin dağılım oranları ile kullanım alanına göre bitki türlerinin dağılım oranları, yuvarlak diyagramda gösterilmiştir. Ayrıca RNA virüslere etkili bitki türleri taranarak; antiviral aktivite çalışmalarından bahsedilmiş ve etnobotanik çalışma ile eşleşen türler tablo halinde gösterilerek tartışılmıştır. Tablolardaki familyalar, türler, etnobotanik çalışma yapılan bölgeler ve Covid-19 belirtilerine uygunluk gösteren tıbbi kullanılışlar alfabetik olarak sıralanmıştır.

\section{BULGULAR}

\section{Pandeminin Kaynağı: Koronavirüsler}

Koronavirüsler

(Latince:

Orthocoronavirinae), Coronaviridae familyasının iki alt familyasından biridir. Alfa, beta, delta ve gama cinsleri mevcuttur. Yarasalarda alfa ve beta koronavirüsler, kuşlarda ise gama ve delta koronavirüsler görülmektedir (Woo ve ark., 2012). Alfa-koronavirüsler; HCoV-229E, HCoV-NL63 (İnsan Koronavirüsleri-Toplum kaynaklı), TGEV (Bulaşıcı Gastroenterit Virüsü), PEDV (Domuz Epidemik Diyare Virüsü), FIPV (Kedi Bulaşıcı Peritonit Virüsü), CCoV (Köpek Koronavirüsü), beta-koronavirüsler; $\mathrm{HCoV}$ OC43, HCoV-HKU1 (İnsan KoronavirüsleriToplum kaynakl1), MHV (Fare Hepatit Virüsü), $\mathrm{BCoV}$ (Büyükbaş Koronavirüsü), SARS-CoV (Şiddetli Akut Solunum Yolu Sendromu Koronavirüsü), MERS-CoV (Orta Doğu Solunum Sendromu Koronavirüsü), SARS-CoV-2 (Şiddetli Akut Solunum Yolu Sendromu Koronavirüsü-2), delta-koronavirüsler; PDCoV (Domuz Delta Koronavirüsü) ve gama-koronavirüsler; IBV (Kuş Bulaşıcı Bronşit Virüsü) olarak siniflandirılmaktadir (Groneberg ve ark., 2005; Fehr ve Perlman, 2015; CDC, 2019; Aanouza ve ark., 2020; İlbay; Strephonsays, 2021).

Koronavirüslerin varlığ dayanmaktadır (Wertheim ve ark., 2013). İlk koronavirüs vak'ası, 1912'de Alman veterinerler tarafından kedide tanımlanmış; elektron mikroskobunda güneşin taç küresine (Corona) benzerliklerinden dolayı bu virüslere 1968 'de koronavirüs adı verilmiştir (Şekil 1) (Woo ve ark., 2012; Mani ve ark., 2020). 
Journal of Integrative and Anatolian

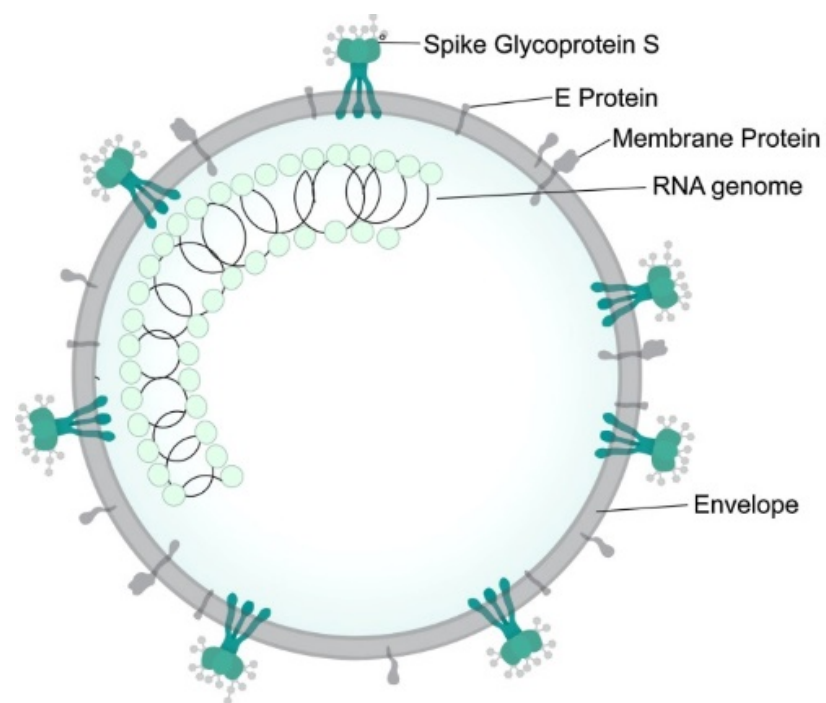

Şekil 1. Koronavirüslerin Yapısı (Mani ve ark., 2020)

Çapları yaklaşık $125 \mathrm{~nm}$ ve yaklaşık 30000 gen taşıyan koronavirüslerin genetik materyali, artı yüklü tek iplikçikli RNA virüsleridirler (Fehr ve Perlman, 2015; Cyranoski, 2020).

Keşfedilen ilk virüsler, tavuklarda görülen enfeksiyöz bronşit virüsü ile insanlarda soğuk algınlığı belirtilerine neden olan insan koronavirüsü 229E ve OC43 dir (Geller ve ark., 2012). Daha sonra keşfedilen virüsler, SARSCoV (2003), HCoV, NL63 (2004), HKU1 (2005), MERS-CoV (2012) ve Covid-19 pandemisine sebep olan SARS-CoV-2 (2019) dir (Graham ve Baric, 2020; Cyranoski, 2020). Merkezi Hong Kong olan Şiddetli Akut Solunum Sendromu (SARS) virüsü, 2002-2003 yıllarında dünyada çok sayıda ölüme neden olmuştur (WHO, 2013). Orta Doğu Solunum Sendromu (MERS) ise ilk kez 2012'de Suudi Arabistan'da tespit edilmiştir (WHO, 2017). Çin'in Wuhan şehrinden 2019 y1lında yayılan Şiddetli Akut Solunum Sendromu Koronavirüsü-2 ilk olarak 2019-nCoV olarak isimlendirilmiş; sonradan DSÖ tarafindan SARS-CoV-2 olarak adlandırılmıştır. Kişiler arası bulaşın ilk kanıtı olan çalışma, Lancet dergisinde yayımlanmıştır (The New York Times, 2020; Yuen ve ark.,
2020). DSÖ tarafindan 2019 yılında, SARSCoV-2 nedeniyle Covid-19 pandemisi ilan edilmiştir. 7 Haziran 2021 tarihi itibariyle, dünyada 173,983,404 vak'a, 3,742,011 ölüm ve $157,182,810$ iyileşme, ülkemizde ise 5,287,980 vak'a, 48,164 ölüm, 5,160,774 iyileşme olduğu bildirilmiştir (Worldometers, 2021).

\section{Ankara İlinde Yapılan Etnobotanik Çalışmalar}

$\mathrm{Bu}$ derlemede, Ankara ilinin, AltındağBağlum-Kılıçlar (Sezik ve ark., 2001), Beypazarı-Ayaş-Güdül (Şimşek ve ark., 2004), Çamlıdere (Günbatan ve ark., 2016), Çubuk Çay1-Tatlar arası (Akdağ, 2019), Güdül (Elçi ve Erik, 2006), Haymana (Sarper ve ark., 2009), Polatlı (Avşar-Şabanözü-Çile Dağı) (Ayandın, 2010) ve Yenimahalle-Kazan (Sezik ve ark., 2001) bölgelerinde yapilan etnobotanik çalışmalarda, kullanımları, Covid-19 belirtileri ile uyum gösteren bitkiler Tablo 1'de, etnobotanik çalışma bölgelerine göre; kullanımları Covid-19 belirtileriyle uyumlu bitki türlerinin sayısı ve oranı Tablo 3'te ve yuvarlak diyagramda dağılımı Şekil 2'de verilmiştir. Ayrıca kullanım alanına göre bitki türlerinin sayısı ve oranı Tablo 4'te, kullanım alanına göre bitki türlerinin yuvarlak diyagramda dağılımı Şekil 3'te gösterilmiştir.

Sezik ve arkadaşları tarafından Orta Anadolu'da yapılan etnobotanik çalışmada, Ankara ili için 3 farklı bölgede çalışılmıştır. Tür tayini neticesinde, 40 familyaya ait 103 bitki türünden 291 halk ilacı elde edilmiştir. Ankara ilinde, Lezgi, Bağlum ve Çubuk bölgeleri'ndeki çalışmalar,

Altındağ-Bağlum-Kılıçlar, Yenimahalle-Kazan ve Çubuk-Bala-Peçenek bölgeleri şeklinde yürütülmüştür. YenimahalleKazan bölgesinde 9 türün, solunum yolu rahatsızlığında kullanıldığı görülmüştür. Nigella sativa L. (Ranunculaceae) tohumları soğuk havalarda, sıcak olarak göğüs üzerine uygulanmak suretiyle kullanılmaktadır. 
Yayncs / Publisher

Sağllk Bilimleri Üniversitesi University of Health Sciences
Öksürükte ve pnömonide Sinapis arvensis L. (Brassicaceae) tohumlarının su veya süt ile kaynatılarak göğüs ve boyuna uygulandığı, Brassica oleraceae L.var. capitata DC. (Brassicaceae) yapraklarının ise zeytinyağı ile 1slatılarak sırta uygulandığı görülmektedir. Pnömoni öksürügünde Linum usitatissimum L. (Linaceae) tohumlarının süt ile kaynatılmasıyla hazırlanan lapa, göğüs ve boyuna uygulanarak, Hordeum vulgare L. (Poaceae) tohumlarının süt ile kaynatılmasıyla hazırlanan lapa gece boyunca göğüse zeytinyağı ile sürülerek kullanılmaktadır. Cucurbita pepo L. (Cucurbitaceae) meyveleri ise su ve süt ile kaynatılıp bronşitte sıcakken boyuna uygulanmaktadir. Malus sylvestris Miller ssp. orientalis Browicz. var. orientalis (Rosaceae) meyveleri öksürük kesici olarak ve bronşitte, Cydonia oblonga Mill. (Rosaceae) yapraklarından ve Juniperus oxycedrus L. subsp. oxycedrus L. (Cupressaceae) meyvelerinden hazırlanan dekoksiyon ise öksürük kesici olarak kullanılmaktadır (Sezik ve ark., 2001).

Ankara' nın Beypazarı, Ayaş ve Güdül bölgelerinin etnobotanik özellikleri, Şimşek ve arkadaşları tarafından 2004 yılında araştırılmıştır. 25 bölgede 400 katılım ile gerçekleştirilen araştırmada 35 familyadan 85 tür için, 192 kullanım ortaya konmuştur. Kullanılışların 115'inin tıbbi amaçlı olduğu tespit edilmiştir. Lamiaceae, Malvaceae ve Rosaceae familyalarına ait 10 türün, solunum yolu hastalıklarında kullanılışı verilmiştir. Rosa foetida J. Herrm. (Rosaceae) meyvelerinden hazırlanan dekoksiyonun soğuk algınlığında, Stachys sylvatica L. (Lamiaceae) yaprak dekoksiyonunun öksürükte, Mentha longifolia (L.) Hudson (Lamiaceae) ve Sorbus demostica L. (Rosaceae) yapraklarından hazırlanan dekoksiyonun öksürük ve bronşitte, Paliurus spina-christi Miller (Rhamnaceae) kök dekoksiyonunun ekspektoran olarak, Thymus leucostomus Hausskn. \& Velen. ssp. leucostomus (Lamiaceae) bitkisinin çay infüzyonunun ekspektoran olarak ve bronşitte, Malva neglecta Wallr. (Malvaceae) bitkisinin, Rosa canina L. (Rosaceae) ve Rosa hemisphaerica J. Herrm.'nın meyve dekoksiyonunun bronşitte, Crataegus aronia (L.) Bosch ex DC. var minuta Browicz (Rosaceae) meyvelerinden hazırlanan çay dekoksiyonunun bronşit ve astımda, Urtica dioica L. (Urticaceae) bitkisinin taze iken yenmek suretiyle astımda kullanıldığ edilmiştir (Şimşek ve ark., 2004).

Çamlıdere bölgesi'nde yapılan etnobotanik çalışmada, değişik amaçlarla kullanılan 72 tür tespit edilmiştir. Bunlardan Asteraceae, Brassicaceae, Cistaceae, Cupressaceae, Elaeagnaceae, Fabaceae, Lamiaceae, Liliaceae, Loranthaceae, Lythraceae, Oleaceae, Pinaceae, Rosaceae, Urticaceae familyalarına ait 31 tür, bölge halkı tarafından çeşitli solunum yolu hastalıklarında kullanılmaktadır. Asteraceae familyası bitkilerinden Anthemis armeniaca Freyn \& Sint. çiçeklerinden hazırlanan infüzyonun boğaz ağrısında, Anthemis tinctoria L. var. pallida DC. çiçekleri ve Rosa canina L. (Rosaceae) meyvelerinin dekoksiyonunun öksürük ve soğuk algınlığında, Malus sylvestris (Rosaceae) kabukları ile hazırlanan dekoksiyonun öksürükte, Prunus spinosa L. subsp. dasyphylla (Schur) Domin (Rosaceae) meyvelerinden hazırlanan pestilin öksürük ve soğuk algınlığında, Tanacetum parthenium Sch. Bip. (Asteracee) çiçeklerinin dekoksiyonunun öksürük ve tonsilitte, Elaeagnus angustifolia L. (Elaeagnaceae) ve Thymus praecox Opiz subsp. skorpilii (Velen.) Jalas var. skorpilii'nin yapraklarının, Olea europaea L. (Oleaceae) yaprakları ve Cydonia oblonga (Rosaceae)'nın sararmış yaprakları ile karıştırılarak hazırlanan infüzyonunun öksürükte kullanıldıkları görülmüştür. Glaucium grandiflorum Boiss. \& A. Huet var. torquatum Cullen (Papaveraceae)'un ise boğmaca öksürüğünde çiçeklerinin dekoksiyonu kullanılmaktadir. Tripleurospermum callosum (Boiss. \& Heldr.) E. Hossain çiçeklerinin 

dioica (Urticaceae) tohumları ile Malva neglecta çalışmada, Çubuk Çayı-Tatlar arasındaki bölgede Wallr. yaprakları ile birlikte dekoksiyonu astım, 302 bitki incelenmiş; 163 cins ve 201 tür ile tür bronşit ve nefes darlığında, Cydonia oblonga'nın altı takson olduğu tespit edilmiştir. Bölge yaprak dekoksiyonu nefes darlığı ve bronşitte, bitkilerinin genellikle gıda ve çay olarak Malus sylvestris (Rosaceae) meyveleri nefes kullanıldıkları görülmüsştür. Covid-19 pandemisi darlığı ve göğüs ağrısında tereyağı ile kavrularak açısından değerlendirilebilecek bir kullanılışa yutulmaktadır. Pinus nigra J. F. Arnold subsp. rastlanmamıştır (Akdağ, 2019).

pallasiana (Lamb.) Holmboe (Pinaceae) kök

Doğal olarak 500 bitki türünün yetiştiği sapları ve floemleri ise bronşit ve akciğer Güdül ilçesi belde ve köyleri ile Kızılcahamam rahatsızlıklarında kullanılmaktadır. Allium cepa L. ilçesine bağlı Çeltikçi beldesinde 35 türün (Liliaceae) soğanlarının pişirildikten sonra kullanıldığı görülmüştür. Lamiaceae tüketilmesi ve Sideritis germanicopolitana familyasından sadece Thymus longicaulis C. Bornm. subsp. germanicopolitana (Lamiaceae) Presl. (Lamiaceae) yapraklarının kaynatılmak toprak üstü kısımlarından hazırlanan infüzyonun suretiyle, solunum yolu rahatsızlıklarında içilmesi, soğuk algınlığında etkilidir. Raphanus öksürük kesici olarak kullanıldığı tespit edilmiştir sativus L. (Brassicaceae) yumruları ise soğuk (Elçi ve Erik, 2006).

algınlığında, içi oyularak bal konmakta ve 1 gece bekletilip ve akıtılarak içilmektedir. Tripleurospermum callosum (Boiss. \& Heldr.) E. Hossain çiçeklerinin, Mentha×piperita ve Thymus longicaulis C. Presl. subsp. longicaulis var. subisophyllus (Borbas) Jalas (Lamiaceae) yaprakları ve Urtica dioica (Urticaceae) toprak üstü kısımları ile birlikte hazırlanan dekoksiyonu, Thymus leucotrichus Halácsy var. leucotrichus, Mentha longifolia (L.) Huds. subsp. longifolia (Lamiaceae), Sinapis arvensis L. (Brassicaceae), Cirsium arvense (L.) Scop. subsp. vestitum (Wimmer \& Grab.) (Asteraceae) Petrak yaprakları, Cistus laurifolius L. (Cistaceae) çiçek ve yaprakları, Viscum album L. (Loranthaceae) bitkisi, Juniperus oxycedrus L. (Cupressaceae) ve Juniperus oxycedrus L. subsp. oxycedrus L. meyveleri ve Astragalus microcephalus Willd. (Fabaceae) köklerinden hazırlanan dekoksiyonlar nefes darlığında kullanılmaktadır. Vitis vinifera L. meyvelerinden hazırlanan sirke ateş durumunda etkiliyken; bebeklerdeki ateş için Mentha longifolia (L.) Huds. subsp. longifolia'nın kurutulmuş ezilmiş yaprakları, Lawsonia inermiş (Lythraceae) bitkisi, bal ve yumurta ile karıştırılıp, göğüs ve sırta uygulanarak kullanılmaktadır (Günbatan ve ark., 2016).

Sarper ve arkadaşlarının, Ankara ilinin Haymana ilçesinde 2009 yılında yürüttüğü etnobotanik çalışmada 9 farklı bölgede, 160 kişi ile görüşme yapılmıştır. Bitkilerin 103 kullanılış şeklinden 67'sinin tedavi amaçlı olduğu tespit edilmiştir. Ayrıca bitkilerin kullanılışlarının, çevre bölgelere nazaran farklı olduğu da görülmüştür. Solunum yolu hastalıklarında kullanılan, Lamiaceae ve Rosaceae familyalarına ait 2 tür tespit edilmiştir. Thymus leucostomus Hausskn. \& Velen. ssp. leucostomus (Lamiaceae)'un herba infüzyonu ekspektoran olarak, Rosa canina L. (Rosaceae)'nin meyveleri ise kaynatılarak bronşitte inhalasyon şeklinde kullanılmaktadır (Sarper ve ark., 2009).

Hacer Ayandın'ın, Ankara ili, Polatlı ilçesi, Avşar, Şabanözü ve Çile Dağı bölgesinde 20082010 yılları arasında yaptığı çalışmada ise, 58 familyaya ait 172 cins ve 205 tür toplanmıştır. Bölge bitkilerinin genellikle gıda ve çay olarak kullanıldıkları görülmektedir. Türlerden 29'u ise tıbbi amaçla kullanılmakta olup; Asteraceae, Cupressaceae, Lamiaceae, Liliaceae, Rosaceae ve Scrophulariaceae familyalarına ait 10 türün kullanılışı, solunum yolu rahatsızlıkları ile ilgilidir. Allium cepa L. (Liliacae) ve Allium 
Journal of Integrative and Anatolian Medicine

Bütünleyici ve Anadolu Tıbbı Dergisi
Cilt/ Volume: 2 Sayı / Issue: 3 Yl1/Year: 2021
Yayınc / Publisher Sağlk Bilimleri Üniversitesi University of Health Sciences sativum L. soğanlarının çiğ olarak yenerek soğuk algınlığında, Anthemis cretica L. subsp. albida (Boiss.) Grierson (Asteraceae) ve Anthemis tinctoria L. var. tinctoria çiçeklerinin demlenerek hazırlanan çayının gargara olarak, Juniperus oxycedrus L. subsp. oxycedrus L. (Cupressaceae) meyvelerinin suda bekletilerek nefes açıcı olarak, Origanum sipyleum L. (Lamiaceae) yapraklarının demlenmek suretiyle ve Verbascum splendidum
Boiss. (Scrophulariaceae) çiçeklerinin kaynatılarak solunum yolu rahatsızliklarında, Rosa canina L. (Rosaceae) meyvelerinden hazırlanan çayın balgam söktürücü, Cydonia oblonga Mill. (Rosaceae) yapraklarından kaynatılarak hazırlanan çayın öksürük kesici ve Junglans regia L. (Juglandaceae) tomurcuklarının astımda yutularak kullanıldıkları belirlenmiştir (Ayandın, 2010). 
Tablo 1- Ankara İli Etnobotanik Çalışmalarında, Kullanılışları Covid-19 Belirtileri ile Uygunluk Gösteren Bitkiler

\begin{tabular}{|c|c|c|c|c|c|c|c|}
\hline Familya & Bitki & Yöresel İsmi & Kullanılan Kısım & Kullanım Alanı & Hazırlanış Şekli & Bölge & Kaynakça \\
\hline Asteraceae & $\begin{array}{c}\text { Anthemis } \\
\text { armeniaca Freyn } \\
\text { \& Sint. }\end{array}$ & Papatya & Çiçek & Boğaz ağrıs1 & İnfüzyon hazırlanır & Çamlıdere & $\begin{array}{l}\text { Günbatan ve } \\
\text { ark., } 2016\end{array}$ \\
\hline Asteraceae & $\begin{array}{c}\text { Anthemis cretica L. } \\
\text { subsp. albida } \\
\text { (Boiss.) Grierson }\end{array}$ & $\begin{array}{l}\text { Papatya, } \\
\text { Biyela, } \\
\text { Çiviyeçe }\end{array}$ & Çiçek & Gargara & $\begin{array}{l}\text { Çay olarak } \\
\text { demlenir }\end{array}$ & $\begin{array}{l}\text { Polatlı Avşar } \\
\text { Köyü }\end{array}$ & Ayandın, 2010 \\
\hline Asteraceae & $\begin{array}{c}\text { Anthemis tinctoria } \\
\text { L. var. } \\
\text { pallida } \text { DC. }\end{array}$ & Papatya & Çiçek & $\begin{array}{c}\text { Öksürük } \\
\text { Soğuk algınlığı }\end{array}$ & $\begin{array}{c}\text { Dekoksiyon } \\
\text { hazırlanır }\end{array}$ & Çamlıdere & $\begin{array}{l}\text { Günbatan ve } \\
\text { ark., } 2016\end{array}$ \\
\hline Asteraceae & $\begin{array}{l}\text { Anthemis tinctoria } \\
\text { L. var. tinctoria }\end{array}$ & $\begin{array}{l}\text { Sarı papatya, } \\
\text { Juta, Lalitsa }\end{array}$ & Çiçek & Gargara & $\begin{array}{c}\text { Çay olarak } \\
\text { demlenir }\end{array}$ & $\begin{array}{l}\text { Polatlı Avşar } \\
\text { Köyü }\end{array}$ & Ayandin, 2010 \\
\hline Asteraceae & $\begin{array}{l}\text { Cirsium arvense } \\
\text { (L.) Scop. subsp. } \\
\text { vestitum (Wimmer } \\
\text { \& Grab.) Petrak }\end{array}$ & Mayasıl otu & Yaprak & Nefes darlığ1 & $\begin{array}{l}\text { Dekoksiyon } \\
\text { hazırlanır }\end{array}$ & Çamlıdere & $\begin{array}{l}\text { Günbatan ve } \\
\text { ark., } 2016\end{array}$ \\
\hline Asteraceae & $\begin{array}{c}\text { Tanacetum } \\
\text { parthenium Sch. } \\
\text { Bip. }\end{array}$ & Papatya & Çiçek & Öksürük & $\begin{array}{l}\text { Dekoksiyon } \\
\text { hazırlanır }\end{array}$ & Çamlıdere & $\begin{array}{l}\text { Günbatan ve } \\
\text { ark., } 2016\end{array}$ \\
\hline
\end{tabular}


Journal of Integrative and Anatolian Medicine

Bütünleyici ve Anadolu Tıbbı Dergisi
Cilt/ Volume: 2 Sayı / Issue: 3 Yll/Year: 2021
Yayınc / Publisher

Sağllk Bilimleri Üniversitesi University of Health Sciences

\begin{tabular}{|c|c|c|c|c|c|c|c|}
\hline Familya & Bitki & Yöresel İsmi & Kullanılan Kısım & Kullanım Alanı & Hazırlanış Şekli & Bölge & Kaynakça \\
\hline Asteraceae & $\begin{array}{l}\text { Tripleurospermum } \\
\text { callosum (Boiss. \& } \\
\text { Heldr.) E. Hossain }\end{array}$ & Akbaba otu & Çiçek & Nefes darlığ 1 & $\begin{array}{c}\text { Mentha } \times \text { piperita } \\
\text { ve Thymus } \\
\text { longicaulis subsp. } \\
\text { longicaulis var. } \\
\text { subisophyllus } \\
\text { yaprakları, Urtica } \\
\text { dioica toprak üstü } \\
\text { kısımları ile birlikte } \\
\text { dekoksiyon } \\
\text { hazırlanır }\end{array}$ & Çamlıdere & $\begin{array}{l}\text { Günbatan ve } \\
\text { ark., } 2016\end{array}$ \\
\hline Asteraceae & & $\begin{array}{l}\text { Papatya, } \\
\text { Göde }\end{array}$ & Çiçek & Soğuk algınlığ 1 & $\begin{array}{l}\text { Dekoksiyon } \\
\text { hazırlanır }\end{array}$ & Çamlıdere & $\begin{array}{c}\text { Günbatan ve } \\
\text { ark., } 2016\end{array}$ \\
\hline Asteraceae & & $\begin{array}{l}\text { Papatya, } \\
\text { Göde }\end{array}$ & Çiçek & $\begin{array}{c}\text { Astım, bronşit, nefes } \\
\text { darlığ } 1\end{array}$ & $\begin{array}{c}\text { Urtica dioica } \\
\text { tohumları ve Malva } \\
\text { neglecta tamamı ile } \\
\text { birlikte dekoksiyon } \\
\text { hazırlanır }\end{array}$ & Çamlıdere & $\begin{array}{l}\text { Günbatan ve } \\
\text { ark., } 2016\end{array}$ \\
\hline Brassicaceae & $\begin{array}{c}\text { Brassica oleraceae } \\
\text { L.var. capitata } \\
\text { DC. }\end{array}$ & Lahana & Yaprak & Öksürük ve pnömoni & $\begin{array}{l}\text { Taze yapraklar } \\
\text { zeytinyağı ile } \\
\text { 1slatılarak sirta } \\
\text { uygulanır }\end{array}$ & $\begin{array}{l}\text { Yenimahalle- } \\
\text { Kazan }\end{array}$ & $\begin{array}{l}\text { Sezik ve ark., } \\
2001\end{array}$ \\
\hline
\end{tabular}


Journal of Integrative and Anatolian Medicine

Bütünleyici ve Anadolu Tıbbı Dergisi
Cilt/ Volume: 2 Sayı / Issue: 3 Yll/Year: 2021
Yayınc / Publisher

Sağllk Bilimleri Üniversitesi University of Health Sciences

\begin{tabular}{|c|c|c|c|c|c|c|c|}
\hline Familya & Bitki & Yöresel İsmi & Kullanılan Kısım & Kullanım Alanı & Hazırlanış Şekli & Bölge & Kaynakça \\
\hline Brassicaceae & $\begin{array}{c}\text { Raphanus sativus } \\
\text { L. }\end{array}$ & Karaturp & Yumru & $\begin{array}{c}\text { Soğuk algınlığında } \\
\text { içilerek }\end{array}$ & $\begin{array}{l}\text { İçi oyulur, bal } \\
\text { konarak } 1 \text { gece } \\
\text { bekletilir, akıtılır }\end{array}$ & Çamlıdere & $\begin{array}{l}\text { Günbatan ve } \\
\text { ark., } 2016\end{array}$ \\
\hline Brassicaceae & Sinapis arvensis L. & Isitma otu & Yaprak & Nefes darlığ 1 & $\begin{array}{l}\text { Dekoksiyon } \\
\text { hazırlanır }\end{array}$ & Çamlıdere & $\begin{array}{l}\text { Günbatan ve } \\
\text { ark., } 2016\end{array}$ \\
\hline Brassicaceae & & Hardal & Tohum & $\begin{array}{c}\text { Öksürük } \\
\text { Pnömonide göğüs ve } \\
\text { boyuna }\end{array}$ & $\begin{array}{l}\text { Ezilerek su ya da } \\
\text { süt ile kaynatılır }\end{array}$ & $\begin{array}{l}\text { Yenimahalle- } \\
\text { Kazan }\end{array}$ & $\begin{array}{l}\text { Sezik ve ark., } \\
2001\end{array}$ \\
\hline Cistaceae & $\begin{array}{c}\text { Cistus laurifolius } \\
\text { L. }\end{array}$ & Süt püşüren & Çiçek, Yaprak & Nefes darlığ1 & $\begin{array}{l}\text { Dekoksiyon } \\
\text { hazırlanır }\end{array}$ & Çamlıdere & $\begin{array}{l}\text { Günbatan ve } \\
\text { ark., } 2016\end{array}$ \\
\hline Cucurbitaceae & Cucurbita pepo L. & $\begin{array}{l}\text { Kestane } \\
\text { kabağ1 }\end{array}$ & Meyve & $\begin{array}{c}\text { Bronşitte sıcakken } \\
\text { boyuna }\end{array}$ & $\begin{array}{c}\text { Meyveler ufalanır, } \\
\text { süt ya da su ile } \\
\text { kaynatılır }\end{array}$ & $\begin{array}{l}\text { Yenimahalle- } \\
\text { Kazan }\end{array}$ & $\begin{array}{l}\text { Sezik ve ark., } \\
2001\end{array}$ \\
\hline Cupressaceae & $\begin{array}{c}\text { Juniperus } \\
\text { oxycedrus L. }\end{array}$ & Ardıç & Meyve & Nefes darlığ 1 & $\begin{array}{l}\text { Dekoksiyon } \\
\text { hazırlanır }\end{array}$ & Çamlıdere & $\begin{array}{l}\text { Günbatan ve } \\
\text { ark., } 2016\end{array}$ \\
\hline Cupressaceae & $\begin{array}{c}\text { Juniperus } \\
\text { oxycedrus L. } \\
\text { subsp. oxycedrus } \\
\text { L. }\end{array}$ & Diken ardıç & Meyve & $\begin{array}{l}\text { Nefes açıcı olarak } \\
\text { içilerek }\end{array}$ & Suda bekletilir & $\begin{array}{l}\text { Polatlı Avşar } \\
\text { Köyü, Çile } \\
\text { Dağ1 }\end{array}$ & Ayandin, 2010 \\
\hline
\end{tabular}


Journal of Integrative and Anatolian Medicine

Bütünleyici ve Anadolu Tıbbı Dergisi
Cilt/ Volume: 2 Sayı / Issue: 3 Yil/Year: 2021
Yayınc / Publisher

Sağllk Bilimleri Üniversitesi University of Health Sciences

\begin{tabular}{|c|c|c|c|c|c|c|c|}
\hline Familya & Bitki & Yöresel İsmi & Kullanılan Kısım & Kullanım Alanı & Hazırlanış Şekli & Bölge & Kaynakça \\
\hline Cupressaceae & $\begin{array}{c}\text { Juniperus } \\
\text { oxycedrus L. }\end{array}$ & Ardıç & Meyve & Nefes darlı̆g 1 & $\begin{array}{c}\text { Dekoksiyon } \\
\text { hazırlanır }\end{array}$ & Çamlıdere & $\begin{array}{c}\text { Günbatan ve } \\
\text { ark., } 2016\end{array}$ \\
\hline Cupressaceae & $\begin{array}{c}\text { Juniperus } \\
\text { oxycedrus L. }\end{array}$ & Ardıç & Meyve & Öksürük & $\begin{array}{c}\text { Dekoksiyon } \\
\text { hazırlanır }\end{array}$ & $\begin{array}{c}\text { Yenimahalle- } \\
\text { Kazan }\end{array}$ & $\begin{array}{c}\text { Sezik ve ark., } \\
2001\end{array}$ \\
\hline Elaeagnaceae & $\begin{array}{c}\text { Elaeagnus } \\
\text { angustifolia L. }\end{array}$ & İğde & Yaprak & Öksürükte içilerek & $\begin{array}{c}\text { Thymus praecox } \\
\text { subsp. skorpilii var. } \\
\text { skorpiliii, } \\
\text { Olea europaea } \\
\text { yaprakları ve } \\
\text { Cydonia } \\
\text { oblonga'nın } \\
\text { sararmış yaprakları } \\
\text { ile karıştırılarak } \\
\text { infüzyon hazırlanır }\end{array}$ & Çamlıdere & $\begin{array}{l}\text { Günbatan ve } \\
\text { ark., } 2016\end{array}$ \\
\hline Fabaceae & $\begin{array}{c}\text { Astragalus } \\
\text { microcephalus } \\
\text { Willd. }\end{array}$ & Geven & Kök & $\begin{array}{l}\text { Nefes darlığ } \\
\text { Bronşit }\end{array}$ & $\begin{array}{c}\text { Dekoksiyon } \\
\text { hazırlanır }\end{array}$ & Çamlıdere & $\begin{array}{l}\text { Günbatan ve } \\
\text { ark., } 2016\end{array}$ \\
\hline Juglandaceae & Junglans regia L. & Ceviz, Ora & Tomurcuk & Astımda yutularak & Tomurcuk hainde & $\begin{array}{l}\text { Polatlı Avşar } \\
\text { Köyü }\end{array}$ & Ayandin, 2010 \\
\hline Lamiaceae & $\begin{array}{l}\text { Mentha longifolia } \\
\text { (L.) Hudson }\end{array}$ & Yarpuz & Yaprak & $\begin{array}{c}\text { Öksürük } \\
\text { Bronşit }\end{array}$ & $\begin{array}{c}\text { Dekoksiyon } \\
\text { hazırlanır }\end{array}$ & $\begin{array}{l}\text { Beypazar1- } \\
\text { Ayaş-Güdül }\end{array}$ & $\begin{array}{l}\text { Şimşek ve } \\
\text { ark., } 2004\end{array}$ \\
\hline
\end{tabular}


Journal of Integrative and Anatolian Medicine

Bütünleyici ve Anadolu Tıbbı Dergisi
Cilt/ Volume: 2 Sayı / Issue: 3 Yll/Year: 2021
Yayınc / Publisher

Sağllk Bilimleri Üniversitesi University of Health Sciences

\begin{tabular}{|c|c|c|c|c|c|c|c|}
\hline Familya & Bitki & Yöresel İsmi & Kullanılan Kısım & Kullanım Alanı & Hazırlanış Şekli & Bölge & Kaynakça \\
\hline Lamiaceae & $\begin{array}{l}\text { Mentha longifolia } \\
\text { (L.) Huds. subsp. } \\
\text { longifolia }\end{array}$ & Nane & Yaprak & Nefes darlığ 1 & $\begin{array}{l}\text { Dekoksiyon } \\
\text { hazırlanır }\end{array}$ & Çamlıdere & $\begin{array}{l}\text { Günbatan ve } \\
\text { ark., } 2016\end{array}$ \\
\hline Lamiaceae & $\begin{array}{l}\text { Mentha longifolia } \\
\text { (L.) Huds. subsp. } \\
\text { longifolia }\end{array}$ & Nane & Yaprak & $\begin{array}{c}\text { Bebeklerdeki ateşte } \\
\text { göğüs ve sırta } \\
\text { uygulanarak }\end{array}$ & $\begin{array}{l}\text { Kurutulmuş ezilmiş } \\
\text { yapraklar bal, } \\
\text { Lawsonia inermiş } \\
\text { ve yumurta ile } \\
\text { karıştırılır }\end{array}$ & Çamlıdere & $\begin{array}{l}\text { Günbatan ve } \\
\text { ark., } 2016\end{array}$ \\
\hline Lamiaceae & $\begin{array}{c}\text { Mentha } \times \text { piperita } \\
\text { L. }\end{array}$ & Nane & Yaprak & Nefes darlığ1 & $\begin{array}{l}\text { Thymus longicaulis } \\
\text { subsp. longicaulis } \\
\text { var. subisophyllus } \\
\text { yaprakları, Urtica } \\
\text { dioica toprak üstü } \\
\text { k1sımları ile birlikte } \\
\text { dekoksiyon } \\
\text { hazırlanır }\end{array}$ & Çamlıdere & $\begin{array}{l}\text { Günbatan ve } \\
\text { ark., } 2016\end{array}$ \\
\hline Lamiaceae & $\begin{array}{l}\text { Origanum } \\
\text { sipyleum L. }\end{array}$ & Mor çay & Çiçek & Solunum yolu hast. & Kaynat1lır & $\begin{array}{l}\text { Polatlı Avşar } \\
\text { Köyü, Çile } \\
\text { Dağı }\end{array}$ & Ayandin, 2010 \\
\hline Lamiaceae & $\begin{array}{c}\text { Sideritis } \\
\text { germanicopolitana } \\
\text { Bornm. subjçsp. } \\
\text { germanicopolitana }\end{array}$ & Adaçayı & Toprak üstü & Soğuk algınlığ & İnfüzyon hazırlanır & Çamlıdere & $\begin{array}{l}\text { Günbatan ve } \\
\text { ark., } 2016\end{array}$ \\
\hline
\end{tabular}


Journal of Integrative and Anatolian Medicine

Bütünleyici ve Anadolu Tıbbı Dergisi
Cilt/ Volume: 2 Sayı / Issue: 3 Yll/Year: 2021
Yayınc / Publisher

Sağllk Bilimleri Üniversitesi University of Health Sciences

\begin{tabular}{|c|c|c|c|c|c|c|c|}
\hline Familya & Bitki & Yöresel İsmi & Kullanılan Kısım & Kullanım Alanı & Hazırlanış Şekli & Bölge & Kaynakça \\
\hline Lamiaceae & $\begin{array}{c}\text { Stachys sylvatica } \\
\text { L. }\end{array}$ & Turunç & Yaprak & Öksürük & $\begin{array}{l}\text { Dekoksiyon } \\
\text { hazırlanır }\end{array}$ & $\begin{array}{l}\text { Beypazar1- } \\
\text { Ayaş-Güdül }\end{array}$ & $\begin{array}{l}\text { Şimşek ve } \\
\text { ark., } 2004\end{array}$ \\
\hline Lamiaceae & $\begin{array}{l}\text { Thymus } \\
\text { leucotrichus } \\
\text { Halácsy var. } \\
\text { leucotrichus }\end{array}$ & Kekik & Yaprak & Nefes darlığ 1 & $\begin{array}{c}\text { Dekoksiyon } \\
\text { hazırlanır }\end{array}$ & Çamlıdere & $\begin{array}{l}\text { Günbatan ve } \\
\text { ark., } 2016\end{array}$ \\
\hline Lamiaceae & $\begin{array}{c}\text { Thymus } \\
\text { leucostomus } \\
\text { Hausskn. \& Velen. } \\
\text { ssp. leucostomus }\end{array}$ & Kekik & Bütün bitki & $\begin{array}{c}\text { Bronşit } \\
\text { Ekspektoran }\end{array}$ & İnfüzyon hazırlanır & $\begin{array}{l}\text { Beypazarı- } \\
\text { Ayaş-Güdül }\end{array}$ & $\begin{array}{l}\text { Şimşek ve } \\
\text { ark., } 2004\end{array}$ \\
\hline Lamiaceae & & & Toprak üstü & Ekspektoran & İnfüzyon hazırlanır & Haymana & $\begin{array}{c}\text { Sarper ve ark., } \\
2009\end{array}$ \\
\hline Lamiaceae & $\begin{array}{c}\text { Thymus } \\
\text { longicaulis C. } \\
\text { Presl. }\end{array}$ & Kekik & Yaprak & Öksürükte içilerek & Kaynatılır & Güdül & $\begin{array}{l}\text { Elçi ve Erik, } \\
2006\end{array}$ \\
\hline Lamiaceae & $\begin{array}{c}\text { Thymus } \\
\text { longicaulis C.Presl } \\
\text { subsp. longicaulis } \\
\text { var. longicaulis }\end{array}$ & Kekik & Yaprak & Soğuk algınlığ1 & $\begin{array}{c}\text { Dekoksiyon } \\
\text { hazırlanır }\end{array}$ & Çamlıdere & $\begin{array}{l}\text { Günbatan ve } \\
\text { ark., } 2016\end{array}$ \\
\hline
\end{tabular}


Journal of Integrative and Anatolian Medicine

Bütünleyici ve Anadolu Tıbbı Dergisi
Cilt/ Volume: 2 Sayı / Issue: 3 Yll/Year: 2021
Yayınc / Publisher

Sağllk Bilimleri Üniversitesi University of Health Sciences

\begin{tabular}{|c|c|c|c|c|c|c|c|}
\hline Familya & Bitki & Yöresel İsmi & Kullanılan Kısım & Kullanım Alanı & Hazırlanış Şekli & Bölge & Kaynakça \\
\hline Lamiaceae & $\begin{array}{c}\text { Thymus } \\
\text { longicaulis C. } \\
\text { Presl. subsp. } \\
\text { longicaulis var. } \\
\text { subisophyllus } \\
\text { (Borbas) Jalas }\end{array}$ & Kekik & Yaprak & Nefes darlığ1 & $\begin{array}{c}\text { Mentha } \times \text { piperita } \\
\text { ve Thymus } \\
\text { longicaulis subsp. } \\
\text { longicaulis var. } \\
\text { subisophyllus } \\
\text { yaprakları, Urtica } \\
\text { dioica toprak üstü } \\
\text { kısımları ile birlikte } \\
\text { dekoksiyon } \\
\text { hazırlanır }\end{array}$ & Çamlıdere & $\begin{array}{l}\text { Günbatan ve } \\
\text { ark., } 2016\end{array}$ \\
\hline Lamiaceae & $\begin{array}{l}\text { Thymus praecox } \\
\text { Opiz subsp. } \\
\text { skorpilii (Velen.) } \\
\text { Jalas var. skorpilii }\end{array}$ & Kekik & Yaprak & Öksürük & $\begin{array}{c}\text { Olea europaea } \\
\text { yaprakları ve } \\
\text { Cydonia } \\
\text { oblonga'nın } \\
\text { sararmış yaprakları } \\
\text { ile karıştırılarak } \\
\text { infüzyon hazırlanır }\end{array}$ & Çamlıdere & $\begin{array}{l}\text { Günbatan ve } \\
\text { ark., } 2016\end{array}$ \\
\hline Liliaceae & Allium сера L. & Soğan, Luk & Soğan & $\begin{array}{c}\text { Soğuk algınlığında } \\
\text { yenerek }\end{array}$ & Çiğ olarak & $\begin{array}{c}\text { Polatlı } \\
\text { Şabanözü } \\
\text { Köyü }\end{array}$ & Ayandin, 2010 \\
\hline Liliaceae & Allium cepa L. & Kuru soğan & Soğan & $\begin{array}{l}\text { Soğuk algınlığında } \\
\text { tereyeğ ile yutularak }\end{array}$ & Pişirilir & Çamlıdere & $\begin{array}{l}\text { Günbatan ve } \\
\text { ark., } 2016\end{array}$ \\
\hline
\end{tabular}


Journal of Integrative and Anatolian Medicine

Bütünleyici ve Anadolu Tıbbı Dergis
Cilt/ Volume: 2 Sayı / Issue: 3 Yll/Year: 2021
Yayınc / Publisher

Sağllk Bilimleri Üniversitesi University of Health Sciences

\begin{tabular}{|c|c|c|c|c|c|c|c|}
\hline Familya & Bitki & Yöresel İsmi & Kullanılan Kısım & Kullanım Alanı & Hazırlanış Şekli & Bölge & Kaynakça \\
\hline Liliaceae & Allium sativum L. & $\begin{array}{l}\text { Sarımsak, } \\
\text { Biyeli }\end{array}$ & Soğan & Soğuk algınlığı & Çiğ olarak & $\begin{array}{c}\text { Polatlı } \\
\text { Şabanözü } \\
\text { Köyü }\end{array}$ & Ayandin, 2010 \\
\hline Linaceae & $\begin{array}{l}\text { Linum } \\
\text { usitatissimum L. }\end{array}$ & Zeyrek & Tohum & $\begin{array}{l}\text { Pnömonideki } \\
\text { öksürükte }\end{array}$ & $\begin{array}{c}\text { Öğütülmüş } \\
\text { tohumlar süt ile } \\
\text { kaynatılır, lapa } \\
\text { hazırlanarak göğüs } \\
\text { ve boyuna } \\
\text { uygulanır. }\end{array}$ & $\begin{array}{c}\text { Yenimahalle- } \\
\text { Kazan }\end{array}$ & $\begin{array}{l}\text { Sezik ve ark., } \\
2001\end{array}$ \\
\hline Loranthaceae & Viscum album L. & Çam purcu & Bütün bitki & Nefes darlığ1 & $\begin{array}{c}\text { Dekoksiyon } \\
\text { hazırlanır }\end{array}$ & Çamlıdere & $\begin{array}{l}\text { Günbatan ve } \\
\text { ark., } 2016\end{array}$ \\
\hline Lythraceae & $\begin{array}{c}\text { Lawsonia inermis } \\
\text { L. }\end{array}$ & Kina & Yaprak & $\begin{array}{l}\text { Bebek ateşinde } \\
\text { gögüus ve sirta }\end{array}$ & $\begin{array}{l}\text { Kurutulmuş ezilmiş } \\
\text { yapraklar bal, } \\
\text { Lawsonia inermiş } \\
\text { ve yumurta ile } \\
\text { karıştırılır }\end{array}$ & Çamlıdere & $\begin{array}{l}\text { Günbatan ve } \\
\text { ark., } 2016\end{array}$ \\
\hline Malvaceae & $\begin{array}{c}\text { Malva neglecta } \\
\text { Wallr. }\end{array}$ & Ebegümeci & Bütün bitki & Bronşit & $\begin{array}{c}\text { Dekoksiyon } \\
\text { hazırlanır }\end{array}$ & $\begin{array}{l}\text { Beypazar1- } \\
\text { Ayaş-Güdül }\end{array}$ & $\begin{array}{l}\text { Şimşek ve } \\
\text { ark., } 2004\end{array}$ \\
\hline Malvaceae & $\begin{array}{c}\text { Malva neglecta } \\
\text { Wallr. }\end{array}$ & Ebegümeci & Yaprak & Nefes darlığ 1 & $\begin{array}{c}\text { Dekoksiyon } \\
\text { hazırlanır }\end{array}$ & Çamlıdere & $\begin{array}{l}\text { Günbatan ve } \\
\text { ark., } 2016\end{array}$ \\
\hline
\end{tabular}


Journal of Integrative and Anatolian Medicine

Bütünleyici ve Anadolu Tıbbı Dergis
Cilt/ Volume: 2 Sayı / Issue: 3 Yll/Year: 2021
Yayınc / Publisher

Sağllk Bilimleri Universites University of Health Sciences

\begin{tabular}{|c|c|c|c|c|c|c|c|}
\hline Familya & Bitki & Yöresel İsmi & Kullanılan Kısım & Kullanım Alanı & Hazırlanış Şekli & Bölge & Kaynakça \\
\hline Malvaceae & $\begin{array}{c}\text { Malva neglecta } \\
\text { Wallr. }\end{array}$ & Ebegümeci & Bütün bitki & $\begin{array}{l}\text { Soğuk algınlığı } \\
\text { Akciğer ödemi }\end{array}$ & $\begin{array}{l}\text { Dekoksiyon } \\
\text { hazırlanır }\end{array}$ & Çamlıdere & $\begin{array}{c}\text { Günbatan ve } \\
\text { ark., } 2016\end{array}$ \\
\hline Malvaceae & $\begin{array}{c}\text { Malva neglecta } \\
\text { Wallr. }\end{array}$ & Ebegümeci & Bütün bitki & $\begin{array}{c}\text { Nefes darlığ1 } \\
\text { Astım } \\
\text { Bronşit }\end{array}$ & $\begin{array}{l} \\
\text { Mentha × piperita } \\
\text { ve Thymus } \\
\text { longicaulis subsp. } \\
\text { longicaulis var. } \\
\text { subisophyllus } \\
\text { yaprakları, Urtica } \\
\text { dioica toprak üstü } \\
\text { k1sımları ile birlikte } \\
\text { dekoksiyon } \\
\text { hazırlanır }\end{array}$ & Çamlidere & $\begin{array}{c}\text { Günbatan ve } \\
\text { ark., } 2016\end{array}$ \\
\hline
\end{tabular}


Journal of Integrative and Anatolian Medicine

Bütünleyici ve Anadolu Tıbbı Dergisi
Cilt/ Volume: 2 Sayı / Issue: 3 Yll/Year: 2021
Yayınc / Publisher

Sağllk Bilimleri Üniversitesi University of Health Sciences

\begin{tabular}{|c|c|c|c|c|c|c|c|}
\hline Familya & Bitki & Yöresel İsmi & Kullanılan Kısım & Kullanım Alanı & Hazırlanış Şekli & Bölge & Kaynakça \\
\hline Oleaceae & Olea europaea L. & Zeytin & Yaprak & Öksürük & $\begin{array}{c}\text { Thymus praecox } \\
\text { subsp. skorpilii var. } \\
\text { skorpiliii, Olea } \\
\text { europaea } \\
\text { yaprakları ve } \\
\text { Cydonia oblonga' } \\
\text { nın sararmış } \\
\text { yaprakları ile } \\
\text { karıştırılarak } \\
\text { infüzyon haz. }\end{array}$ & Çamlıdere & $\begin{array}{c}\text { Günbatan ve } \\
\text { ark., } 2016\end{array}$ \\
\hline Papaveraceae & $\begin{array}{c}\text { Glaucium } \\
\text { grandiflorum } \\
\text { Boiss. \& A. Huet } \\
\text { var. torquatum } \\
\text { Cullen }\end{array}$ & Gelincik & Çiçek & Boğmaca öksürüğü & $\begin{array}{l}\text { Dekoksiyon } \\
\text { hazırlanır }\end{array}$ & Çamlıdere & $\begin{array}{c}\text { Günbatan ve } \\
\text { ark., } 2016\end{array}$ \\
\hline Pinaceae & $\begin{array}{c}\text { Pinus nigra J. F. } \\
\text { Arnold subsp. } \\
\text { pallasiana (Lamb.) } \\
\text { Holmboe }\end{array}$ & Karaçam & $\begin{array}{c}\text { Kök sapları } \\
\text { Floem }\end{array}$ & $\begin{array}{c}\text { Bronşit } \\
\text { Akciğer hastalıkları } \\
\text { Pnömonide }\end{array}$ & - & Çamlıdere & $\begin{array}{c}\text { Günbatan ve } \\
\text { ark., } 2016\end{array}$ \\
\hline Poaceae & $\begin{array}{c}\text { Hordeum vulgare } \\
\text { L. }\end{array}$ & Arpa & Tohum & Pnömoni öksürüğü & $\begin{array}{l}\text { Tohumlar süt ile } \\
\text { kaynatılır, lapa } \\
\text { hazırlanır, gece } \\
\text { boyunca yağ ile } \\
\text { sürülürek gögüse } \\
\text { uygulanır }\end{array}$ & $\begin{array}{c}\text { Yenimahalle- } \\
\text { Kazan }\end{array}$ & $\begin{array}{c}\text { Sezik ve ark., } \\
2001\end{array}$ \\
\hline
\end{tabular}



Journal of Integrative and Anatolian
Medicine

Bütünleyici ve Anadolu Tıbbı Dergisi
Cilt/ Volume: 2 Sayı / Issue: 3 Yll/Year: 2021
Yayınc / Publisher

Sağllk Bilimleri Üniversitesi University of Health Sciences

\begin{tabular}{|c|c|c|c|c|c|c|c|}
\hline Familya & Bitki & Yöresel İsmi & Kullanılan Kısım & Kullanım Alanı & Hazırlanış Şekli & Bölge & Kaynakça \\
\hline Ranunculaceae & Nigella sativa L. & Çörekotu & Tohum & $\begin{array}{c}\text { Soğuklarda göğüs } \\
\text { üzerine }\end{array}$ & Sicak olarak & $\begin{array}{l}\text { Yenimahalle- } \\
\text { Kazan }\end{array}$ & $\begin{array}{c}\text { Sezik ve ark., } \\
2001\end{array}$ \\
\hline Rhamnaceae & $\begin{array}{c}\text { Paliurus spina- } \\
\text { christi Miller }\end{array}$ & Karaçalı & Kök & Ekspektoran & $\begin{array}{c}\text { Dekoksiyon } \\
\text { hazırlanır }\end{array}$ & $\begin{array}{l}\text { Beypazarı- } \\
\text { Ayaş-Güdül }\end{array}$ & $\begin{array}{l}\text { Şimşek ve } \\
\text { ark., } 2004\end{array}$ \\
\hline Rosaceae & $\begin{array}{c}\text { Crataegus aronia } \\
\text { (L.) Bosch ex DC. } \\
\text { var minuta } \\
\text { Browicz }\end{array}$ & Kuşburnu & Meyve & $\begin{array}{l}\text { Bronşit } \\
\text { Astım }\end{array}$ & $\begin{array}{c}\text { Dekoksiyon } \\
\text { hazırlanır }\end{array}$ & $\begin{array}{l}\text { Beypazarı- } \\
\text { Ayaş-Güdül }\end{array}$ & $\begin{array}{l}\text { Şimşek ve } \\
\text { ark., } 2004\end{array}$ \\
\hline Rosaceae & $\begin{array}{c}\text { Cydonia oblonga } \\
\text { Mill. }\end{array}$ & Ayva & Yaprak & $\begin{array}{l}\text { Nefes darlığg } 1 \\
\text { Bronşit }\end{array}$ & $\begin{array}{l}\text { Dekoksiyon } \\
\text { hazırlanır }\end{array}$ & Çamlıdere & $\begin{array}{l}\text { Günbatan ve } \\
\text { ark., } 2016\end{array}$ \\
\hline
\end{tabular}


Journal of Integrative and Anatolian Medicine

Bütünleyici ve Anadolu Tıbbı Dergis
Cilt/ Volume: 2 Sayı / Issue: 3 Yll/Year: 2021
Yayınc / Publisher

Sağllk Bilimleri Üniversitesi University of Health Sciences

\begin{tabular}{|c|c|c|c|c|c|c|c|}
\hline Familya & Bitki & Yöresel İsmi & Kullanılan Kısım & Kullanım Alanı & Hazırlanış Şekli & Bölge & Kaynakça \\
\hline Rosaceae & $\begin{array}{c}\text { Cydonia oblonga } \\
\text { Mill. }\end{array}$ & Ayva & Yaprak & Öksürük & $\begin{array}{c}\text { Thymus praecox } \\
\text { Opiz subsp. } \\
\text { skorpilii (Velen.) } \\
\text { Jalas var. skorpilii, } \\
\text { Olea europaea } \\
\text { yaprakları ve } \\
\text { Cydonia } \\
\text { oblonga'nın } \\
\text { sararmış yaprakları } \\
\text { ile karıştırılarak } \\
\text { infüzyon hazırlanır }\end{array}$ & Çamlıdere & $\begin{array}{l}\text { Günbatan ve } \\
\text { ark., } 2016\end{array}$ \\
\hline Rosaceae & $\begin{array}{c}\text { Cydonia oblonga } \\
\text { Mill. }\end{array}$ & Ayva & Yaprak & Öksürük & $\begin{array}{c}\text { Malus sylvestris } \\
\text { kabukları ile } \\
\text { dekoksiyon } \\
\text { hazırlanır }\end{array}$ & Çamlıdere & $\begin{array}{l}\text { Günbatan ve } \\
\text { ark., } 2016\end{array}$ \\
\hline Rosaceae & $\begin{array}{c}\text { Cydonia oblonga } \\
\text { Mill. }\end{array}$ & Ayva, Tuuna & Yaprak & Öksürük & Kaynatılır & $\begin{array}{l}\text { Polatl1- } \\
\text { Şabanözü } \\
\text { Köyü }\end{array}$ & Ayandin, 2010 \\
\hline Rosaceae & $\begin{array}{c}\text { Cydonia oblonga } \\
\text { Mill. }\end{array}$ & Ayva & Yaprak & Öksürük & $\begin{array}{c}\text { Dekoksiyon } \\
\text { hazırlanır }\end{array}$ & $\begin{array}{c}\text { Yenimahalle- } \\
\text { Kazan }\end{array}$ & $\begin{array}{c}\text { Sezik ve ark., } \\
2001\end{array}$ \\
\hline
\end{tabular}


Journal of Integrative and Anatolian Medicine

Bütünleyici ve Anadolu Tıbbı Dergis
Cilt/ Volume: 2 Sayı / Issue: 3 Yll/Year: 2021
Yayınc / Publisher

Sağllk Bilimleri Üniversitesi University of Health Sciences

\begin{tabular}{|c|c|c|c|c|c|c|c|}
\hline Familya & Bitki & Yöresel İsmi & Kullanılan Kısım & Kullanım Alanı & Hazırlanış Şekli & Bölge & Kaynakça \\
\hline Rosaceae & $\begin{array}{c}\text { Malus sylvestris } \\
\text { Mill. }\end{array}$ & Elma & Meyve & $\begin{array}{l}\text { Nefes darliğında } \\
\text { yutularak }\end{array}$ & $\begin{array}{c}\text { Tereyağı ile } \\
\text { kavrulur }\end{array}$ & Çamlıdere & $\begin{array}{l}\text { Günbatan ve } \\
\text { ark., } 2016\end{array}$ \\
\hline Rosaceae & $\begin{array}{c}\text { Malus sylvestris } \\
\text { Mill. }\end{array}$ & Elma & Kabuk & Öksürük & $\begin{array}{l}\text { Dekoksiyon } \\
\text { hazırlanır }\end{array}$ & Çamlıdere & $\begin{array}{l}\text { Günbatan ve } \\
\text { ark., } 2016\end{array}$ \\
\hline Rosaceae & $\begin{array}{c}\text { Malus sylvestris } \\
\text { Miller ssp. } \\
\text { orientalis Browicz. } \\
\text { var. orientalis }\end{array}$ & Elma & Meyve & $\begin{array}{c}\text { Öksürükte sicakken } \\
\text { yenerek }\end{array}$ & $\begin{array}{c}\text { Orta kısmı } \\
\text { çıkartılır, tereyağ1 } \\
\text { ile doldurulur, } \\
\text { közde pişirilir, } \\
\text { yenir }\end{array}$ & $\begin{array}{l}\text { Yenimahalle- } \\
\text { Kazan }\end{array}$ & $\begin{array}{l}\text { Sezik ve ark., } \\
2001\end{array}$ \\
\hline Rosaceae & $\begin{array}{c}\text { Malus sylvestris } \\
\text { Miller ssp. } \\
\text { orientalis Browicz. } \\
\text { var. orientalis }\end{array}$ & Elma & Meyve & $\begin{array}{l}\text { Bronşitte göğüse } \\
\text { uygulanarak }\end{array}$ & $\begin{array}{c}\text { Orta kısmı } \\
\text { çıkartılır, karabiber } \\
\text { konur, tekrar } \\
\text { kapatılarak közde } \\
\text { pişirilir }\end{array}$ & $\begin{array}{l}\text { Yenimahalle- } \\
\text { Kazan }\end{array}$ & $\begin{array}{l}\text { Sezik ve ark., } \\
2001\end{array}$ \\
\hline Rosaceae & $\begin{array}{l}\text { Prunus spinosa L. } \\
\text { subsp. dasyphylla } \\
\text { (Schur) Domin }\end{array}$ & Acı erik & Meyve & $\begin{array}{l}\text { Soğuk algınlığı ve } \\
\text { öksürükte içilerek }\end{array}$ & $\begin{array}{l}\text { Pestil hazırlanarak } \\
\text { s1cak suda eritilir }\end{array}$ & Çamlıdere & $\begin{array}{l}\text { Günbatan ve } \\
\text { ark., } 2016\end{array}$ \\
\hline Rosaceae & Rosa canina L. & Kuşburnu & Meyve & Bronşit & $\begin{array}{l}\text { Dekoksiyon } \\
\text { hazırlanır }\end{array}$ & $\begin{array}{l}\text { Beypazar1- } \\
\text { Ayaş- } \\
\text { Güdül }\end{array}$ & $\begin{array}{l}\text { Şimşek ve } \\
\text { ark., } 2004\end{array}$ \\
\hline
\end{tabular}


Journal of Integrative and Anatolian Medicine

Bütünleyici ve Anadolu Tıbbı Dergis
Cilt/ Volume: 2 Sayı / Issue: 3 Yll/Year: 2021
Yayınc / Publisher

Sağllk Bilimleri Üniversitesi University of Health Sciences

\begin{tabular}{|c|c|c|c|c|c|c|c|}
\hline Familya & Bitki & Yöresel İsmi & Kullanılan Kısım & Kullanım Alanı & Hazırlanış Şekli & Bölge & Kaynakça \\
\hline Rosaceae & Rosa canina L. & Yabani gül & Meyve & Bronşit & $\begin{array}{l}\text { Dekoksiyon } \\
\text { hazırlanır }\end{array}$ & $\begin{array}{l}\text { Beypazar1- } \\
\text { Ayaş- } \\
\text { Güdül }\end{array}$ & $\begin{array}{l}\text { Şimşek ve } \\
\text { ark., } 2004\end{array}$ \\
\hline Rosaceae & Rosa canina $\mathrm{L}$. & Kuşburnu & Meyve & Bronşitte inhaler & Kaynatılır & Haymana & $\begin{array}{c}\text { Sarper ve ark., } \\
2009\end{array}$ \\
\hline Rosaceae & Rosa canina L. & Kuşburnu & Meyve & Balgam söktürücü & $\begin{array}{l}\text { Meyve çayı } \\
\text { hazırlanır }\end{array}$ & $\begin{array}{l}\text { Polatlı Avşar } \\
\text { Köyü, Çile } \\
\text { Dağı }\end{array}$ & Ayandin, 2010 \\
\hline Rosaceae & Rosa canina L. & Kuşburnu & Meyve & $\begin{array}{l}\text { Soğuk algınlığ1 ve } \\
\text { öksürükte içilerek }\end{array}$ & $\begin{array}{c}\text { Dekoksiyon } \\
\text { hazırlanır }\end{array}$ & Çamlıdere & $\begin{array}{c}\text { Günbatan ve } \\
\text { ark., } 2016\end{array}$ \\
\hline Rosaceae & $\begin{array}{c}\text { Rosa foetida } \mathrm{J} . \\
\text { Herrm. }\end{array}$ & Kuşburnu & Meyve & Soğuk algınlığı & $\begin{array}{c}\text { Dekoksiyon } \\
\text { hazırlanır }\end{array}$ & $\begin{array}{l}\text { Beypazar1- } \\
\text { Ayaş-Güdül }\end{array}$ & $\begin{array}{l}\text { Şimşek ve } \\
\text { ark., } 2004\end{array}$ \\
\hline Rosaceae & $\begin{array}{c}\text { Rosa } \\
\text { hemisphaerica } \mathrm{J} . \\
\text { Herrm. }\end{array}$ & $\begin{array}{c}\text { Öküzgötü, } \\
\text { Gürüz }\end{array}$ & Meyve & Bronşit & $\begin{array}{c}\text { Dekoksiyon } \\
\text { hazırlanır }\end{array}$ & $\begin{array}{l}\text { Beypazar1- } \\
\text { Ayaş-Güdül }\end{array}$ & $\begin{array}{l}\text { Şimşek ve } \\
\text { ark., } 2004\end{array}$ \\
\hline Rosaceae & $\begin{array}{c}\text { Sorbus demostica } \\
\text { L. }\end{array}$ & Övez & Yaprak & $\begin{array}{l}\text { Öksürük } \\
\text { Bronşit }\end{array}$ & $\begin{array}{c}\text { Dekoksiyon } \\
\text { hazırlanır }\end{array}$ & $\begin{array}{l}\text { Beypazar1- } \\
\text { Ayaş-Güdül }\end{array}$ & $\begin{array}{l}\text { Şimşek ve } \\
\text { ark., } 2004\end{array}$ \\
\hline
\end{tabular}



Journal of Integrative and Anatolian
Medicine

Bütünleyici ve Anadolu Tıbbı Dergisi
Cilt/ Volume: 2 Sayı / Issue: 3 Yli/Year: 2021
Yayınc / Publisher

Sağllk Bilimleri Üniversitesi

University of Health Sciences

\begin{tabular}{|c|c|c|c|c|c|c|c|}
\hline Familya & Bitki & Yöresel İsmi & Kullanılan Kısım & Kullanım Alanı & Hazırlanış Şekli & Bölge & Kaynakça \\
\hline Scrophulariaceae & $\begin{array}{c}\text { Verbascum } \\
\text { splendidum Boiss. }\end{array}$ & $\begin{array}{c}\text { Siğır } \\
\text { kuyruğu, } \\
\text { Divizbina }\end{array}$ & Çiçek & $\begin{array}{l}\text { Solunum yolu } \\
\text { hastalıklarında }\end{array}$ & Kaynatılır & $\begin{array}{l}\text { Polatlı Avşar } \\
\text { Köyü, Çile } \\
\text { Dağı }\end{array}$ & Ayandın, 2010 \\
\hline Urticaceae & Urtica dioica $\mathrm{L}$. & Isırgan & Bütün bitki & Astımda yenerek & Taze olarak & $\begin{array}{l}\text { Beypazar1- } \\
\text { Ayaş-Güdül }\end{array}$ & $\begin{array}{l}\text { Şimşek ve } \\
\text { ark., } 2004\end{array}$ \\
\hline Urticaceae & Urtica dioica L. & Isırgan & Yaprak & Nefes darlığ 1 & $\begin{array}{c}\text { Dekoksiyon } \\
\text { hazırlanır }\end{array}$ & Çamlıdere & $\begin{array}{l}\text { Günbatan ve } \\
\text { ark., } 2016\end{array}$ \\
\hline Urticaceae & Urtica dioica L. & Dalağan & Toprak üstü & Nefes darlığ 1 & $\begin{array}{c}\text { Mentha } \times \text { piperita } \\
\text { ve Thymus } \\
\text { longicaulis subsp. } \\
\text { longicaulis var. } \\
\text { subisophyllus } \\
\text { yaprakları, Urtica } \\
\text { dioica toprak üstü } \\
\text { kısımlarılyla } \\
\text { karıştırılarak } \\
\text { dekoksiyon } \\
\text { hazırlanır }\end{array}$ & Çamlıdere & $\begin{array}{l}\text { Günbatan ve } \\
\text { ark., } 2016\end{array}$ \\
\hline
\end{tabular}


Journal of Integrative and Anatolian Medicine

Bütünleyici ve Anadolu Tıbbı Dergisi
Cilt/ Volume: 2 Sayı / Issue: 3 Yll/Year: 2021
Yayınc / Publisher

Sağllk Bilimleri Universites University of Health Sciences

\begin{tabular}{|c|c|c|c|c|c|c|c|}
\hline Familya & Bitki & Yöresel İsmi & Kullanılan Kısım & Kullanım Alanı & Hazırlanış Şekli & Bölge & Kaynakça \\
\hline Urticaceae & Urtica dioica L. & Dalaz & Tohum & $\begin{array}{c}\text { Astım } \\
\text { Bronşit } \\
\text { Nefes darlığ1 }\end{array}$ & $\begin{array}{c}\text { Urtica dioica } \\
\text { tohumları ve } \\
\text { Malva neglecta } \\
\text { tamamı ile birlikte } \\
\text { dekoksiyonu } \\
\text { hazırlanır }\end{array}$ & Çamlıdere & $\begin{array}{c}\text { Günbatan ve } \\
\text { ark., } 2016\end{array}$ \\
\hline Vitaceae & Vitis vinifera L. & Üzüm & Meyve & Ateşte vücuda & $\begin{array}{l}\text { Meyvelerinden } \\
\text { üzüm sirkesi } \\
\text { hazırlanır }\end{array}$ & Çamlıdere & $\begin{array}{c}\text { Günbatan ve } \\
\text { ark., } 2016\end{array}$ \\
\hline
\end{tabular}


Journal of Integrative and Anatolian Medicine

Bütünleyici ve Anadolu Tıbbı Dergisi
Cilt/ Volume: 2 Sayı / Issue: 3 Yil/Year: 2021
Yayıncı / Publisher

Sağllk Bilimleri Üniversitesi University of Health Sciences

\section{RNA Virüsler Üzerinde Yapılan Antiviral Aktivite Çalışmaları}

Dünyada ve Türkiye'de, koronavirüslere etkili aşı ve ilaç geliştirme çalışmaları yanında; bitkisel ürünlerin de Covid-19 pandemisi üzerinde etkileri araştırılmaktadır. Uygun çözücüler kullanılarak elde edilen bitki ekstraktları ya da izole edilen etken maddelerin, koronavirüslere karşı antiviral aktivite tayinleri yapılmakta ve yayımlanmaktadır (Aanouz ve ark., 2020; Li ve ark., 2020; Patel ve ark., 2020; Şekeroğlu ve Gezici, 2020).

$\mathrm{Bu}$ derlemede, Ankara ilinde yapilan etnobotanik çalışmalarda tespit edilen türlere ilaveten; Ankara ili florasında yer alan ve çeşitli koronavirüslere karşı antiviral aktivite çalışmaları yapılmış cins ve türler incelenmiştir. Bitki ekstraktları ve uçucu yağları üzerinde antiviral aktivite çalışmaları yapılmış 6 tür, Ankara florasında yer almakta olup; halk ilacı olarak kullanılmaktadır. 2 türe ait yurt içinde ve 4 türe ait yurt dışında yapılmış antiviral aktivite çalışmaları ve sonuçları Tablo 2'de özet halinde gösterilmiştir.

Allium sativum L. (Liliaceae) üzerinde yapılan antiviral aktivite çalışmasında, taze yumruların kabukları soyularak kalan temiz kısım kullanılmıştır. Ekstrenin kültüre tatbikinden 1,8 ve 24 saat sonra influenza virüsüne karşı etkisi çalışılmıştır. MDCK (Madin-Darbey Canine Kidney) hücreleri, farklı zamanlarda, 100 TCID $_{50} \quad(\% 50$ doku kültür enfeksiyon dozu) dozda virüs ve etkili en az sitotoksik olan konsantrasyondaki ekstre ile muamele edilmiştir. RNA ekstraksiyonu ile muameleden sonra, farklı zamanlarda sentezlenen viral genom miktarını ölçmek için, RT-PCR ve serbest bant dansidometrisi uygulanmıştır. Sonuçta, iyi bir SI (selektif indeks)' e sahip Allium ekstresinin, hücre kültüründe virüs nüfuz ve çoğalması üzerinde inhibitör etkisinin olduğu görülmüştür (Mehr ve ark., 2009).
In vivo ortamda influenza $\mathrm{B}$ virüsüne karş1 çalışılan Allium sativa L. ekstraktı, farelere verildiğinde, antikor üretimini iyileştirmek suretiyle koruyucu etki gösterdiği tespit edilmiştir (Batiha ve ark., 2020).

Türkiye'de Ulaşlı ve arkadaşları tarafından bitkiler üzerinde yapılan antiviral aktivite çalışmasında, Anthemis hyalina DC. (Asteraceae)'nın çiçek ve tomurcuklarından ve Nigella sativa L. (Ranunculaceae)'nın tohumlarında hazırlanan ekstrakt, MHV-A59 (Fare Hepatit Virüsü)'ya karşı test edilmiştir. 1/50 oranında dilüe edilerek kullanılan ekstraktlar, virüsle enfekte edilen HeLaCEACAM hücrelerinde, virüsün çoğalmasını engellemiştir. Anthemis hyalina DC'nın etkisi, Nigella sativa L.'dan yüksek bulunmuştur. Intrasellüler kalsiyum seviyesinde artış meydana gelmiş ve Potansiyelankirin 1, geçici reseptör potansiyel kanal 4, geçici reseptör potansiyel katyon kanal alt familyası M, TRPM7, TRPM8 ve geçici reseptör potansiyel katyon kanal alt familyası $\mathrm{V}$ genini değiştirdiği de görülmüştür (Ulaşlı ve ark., 2014).

Cistus laurifolius L. (Cistaceae) üzerinde yapılan aktivite tayininde, yaprakların hekzan ekstraktının, 32-8 $\mu \mathrm{g} / \mathrm{mL}$, konsantrasyonda Parainfluenza-3 virüsüne karş1 antiviral etki gösterdiği tespit edilmiştir (Ustun ve ark., 2016).

Juniperus oxycedrus L. subsp. oxycedrus L. (Cupressaceae) ve Salvia officinalis L. (Lamiaceae)'in meyve uçucu yağlarının, SARSCoV'a karşı etkisi çalışılmıştır. Kontrol amaçlı Glisirizin kullanılmıştır. Çalışmada, sitopatojenik etki de tespit edilmiştir. $J$. oxycedrus subsp. oxycedrus L.'un uçucu yağının, Salvia officinalis L. uçucu yağından daha güçlü etkiye sahip olduğu görülmüş; $\mathrm{IC}_{50}$ değeri $270 \pm$ $1.5 \mu \mathrm{g} / \mathrm{mL}$ ve SI değeri 3.7 olarak tespit edilmiştir. Glisirizin ( $\mathrm{IC}_{50} 641 \mathrm{mg} / \mathrm{mL}$; SI=1.2) ile karşılaştırıldığında; SARS-CoV'u inhibisyon etkisinin daha yüksek ve güvenlik sınırının daha geniş olduğu görülmüştür. Uçucu yağların toksisitesi, Vero hücrelerinde, $120-1000 \mu \mathrm{g} / \mathrm{mL}$ 
Journal of Integrative and Anatolian Medicine

Bütünleyici ve Anadolu Tıbbı Dergisi
Cilt/ Volume: 2 Sayı / Issue: 3 Yil/Year: 2021
Yayıncı / Publisher

Sağllk Bilimleri Üniversitesi University of Health Sciences aralığında test edilmişlerdir (Loizzo ve ark., 2008).

Kuş Bulaşıcı Bronşit Virüsü (IBV)'ne karşı yapılan antiviral aktivite tayininde, Lamiaceae familyası bitkilerinden; Mentha officinalis L., Mentha piperita L., Origanum vulgare L., Salvia officinalis L., Thymus vulgaris L. bitkilerinin toprak üstü kısımlarının etanol ekstreleri kullanılmıştır. Dulbecco'nun modifiye Eagle's ortamında (DMEM) Vero hücreleri ve Baudette IBV ile in vitro ortamda 4 ayr1 metot uygulanmıştır. Mikroskobik inceleme sonunda EC50 ve selektivite indeksi (SI) tayini için, en etkili olabilecek bitki ekstraktları seçilmiştir. Bütün ekstraktlar, enfeksiyon esnasında ve öncesinde IBV'ye karşı etkili bulunmuştur. SI değeri 60'tan büyük olan Mentha piperita ve Thymus vulgaris'in en fazla etkiyi gösterdikleri tespit edilmiştir (Lelesius ve ark., 2019).

Origanum vulgare L. (Lamiaceae) üzerinde, Büyükbaş Viral Diyare Virüsü (BVDV), At Arterit Virüsü (EAV), At İnfluenza Virüsü (EIV), Kedi Kalikivirüsü (FCV), Köpek Distemper Virüsü (CDV) ve Köpek Koronavirüsü (CCoV)'ne karşı aktivite çalışmaları yapılmıştır. Bitkinin su ve etanol ekstreleri kullanılmıştır. $1600 \mu \mathrm{g} / \mathrm{mL}$ sulu ekstrakt ve $600 \mu \mathrm{g} / \mathrm{mL}$ etanol ekstraktı, Madin Darby büyükbaş böbrek hücreleri (MDBK), tavşan böbrek hücreleri (RK 13), Madin Darby köpek böbrek hücreleri (MDCK) ve Crandell kedi böbrek hücreleri (CRFK) üzerinde sitotoksik etki göstermemiştir. O. Vulgare'nin sulu ekstraktı, \%50 ( TCID $\left._{50}\right)$ EAV titresinin, 105.42 'den 102.09 TCID $_{50} / 100$ $\mu \mathrm{L}$ ye kadar azalmasını sağlamıştır. Etanol ekstraktı ise, titreyi 105.42 'den 100.79 TCID ${ }_{50} / 100 \mu \mathrm{L}$ 'ye önemli derecede azaltmıştır. Sulu ekstrakta CDV ilavesi, bu değeri, 102'den 100 $\mathrm{TCID}_{50} / 100 \mu \mathrm{L}$ 'ye, etanol ekstraktına ilavesi, 102 'den $101.50 \mathrm{TCID}_{50} / 100 \mu \mathrm{L}$ 'ye düşürmüştür. Etanol ekstraktı, EAV'e karşı önemli antiviral etki göstermiş; her iki ekstraktın da CDV'e karşı antiviral aktivitesinin yüksek olduğu tespit edilmiştir. Sulu ekstraktın sitotoksisitesi ise bütün gruplarda $1600 \mu \mathrm{g} / \mathrm{mL}$ konsantrasyonda gözlenmiştir. Etanol ekstraktının ise, $600 \mu \mathrm{g} / \mathrm{mL}$ konsantrasyonda geçirgenliği \%100 olarak tespit edilmiştir. Ekstraktlar, BVDV, EIV, FCV, CAV ve $\mathrm{CCoV}$ üzerinde etkili bulunmamıştır (Blank ve ark., 2019).

Potentilla arguta Pursh. (Rosaceae)'nın dallarından hazırlanan ektrakt ile yapılan çalışmada, Solunum Sinsityal Virüsü RSV'yi inhibe ettiği görülmüştür (Kotwal ve ark., 2005) Ayrıca köklerinden hazırlanan metanol ekstresi, Sığır Sinsityal Solunum Virüsünün (BRSV) çoğalmasını engellemiştir (Ökdem, 2017).

Trifolium africanum Ser. (Fabaceae)'dan hazırlanan ekstraktın ise, virüs girişini engelleyerek SARS-CoV'ünü inhibe ettiği tespit edilmiştir (Kotwal ve ark., 2005).

Rosaceae familyasından Prunus yedoensis, $P$. Sargentii, P. Lannesiana cv. ve P. Cerasus L. kültür bitkilerinin çiçekleri, Vero hücrelerinde, Domuz Epidemik Diyare Virüsü (PEDV)'ne karş1 test edilmiştir. Prunus cerasus, $1.95 \mu \mathrm{g} / \mathrm{mL}$ konsantrasyonda, viral replikasyonu önlemek suretiyle, sitopatojenik etkinin (CPE) \%50'sini inhibe ederek en yüksek etkiyi göstermiştir (Yook ve ark., 2010).

Rosa türleri üzerinde yapılan antiviral aktivite çalışmalarında, Rosa canina L. (Rosaceae) bitkisinin in vitro ortamda Solunum Sinsityal Virüse (RSV) karşı (Güçlü ve Yüksel, 2017) ve Rosa nutkana C. Presl' nın dallarından hazırlanan ekstraktın ise Büyükbaş Orijinli Enterik Koronavirüse $(\mathrm{BCoV})$ karşı etkili olduğu gösterilmiştir (Lans ve ark., 2007).

Thymus vulgaris L. (Lamiaceae) üzerinde Domuz Üreme ve Solunum Sendromu (PRRS) virüsüne karşı yapılan çalışmada, bitkinin toprak üstü kısımları su ile distile edilerek yoğunlaştırılmıştır. In vitro ortamda antiviral aktivite tayinini gerçekleştirmek üzere, Dulbecco'nun modifiye Eagle's ortaminda (DMEM) MARC-145 hücreleri kullanılmıştır. 
Journal of Integrative and Anatolian Medicine

Bütünleyici ve Anadolu Tıbbı Dergisi
Cilt/ Volume: 2 Sayı / Issue: 3 Yl1/Year: 2021
Yayınc1 / Publisher Sağlk Bilimleri Üniversitesi University of Health Sciences

Thymus sulu alkollü çözeltileri, A basamağında adsorbsiyon, replikasyon ve salınımı bloke hücre konformasyonunu değiştirdiği, B etmesi nedeniyle; PRRSV enfeksiyonunun basamağında viral bağlanmayı engellediği ve son tedavisinde ve profilaksisinde güçlü bir terapötik basamakta virüs salınım ya da replikasyonunu olduğu tespit edilmiştir (Kaewprom ve ark., önlediği gösterilmiştir. Viral bağlanma, 2017).

Tablo 2. Bitkiler ve Etkili Oldukları RNA Virüsler

\begin{tabular}{|c|c|c|}
\hline Bitki Türleri & RNA Virüsler & Kaynakça \\
\hline Allium sativum L. & Influenza B & Batiha ve ark., 2020 \\
\hline Cistus laurifolius L. & Parainfluenza-3 & Ustun ve ark., 2021 \\
\hline Juniperus oxycedrus L. subsp. oxycedrus L. & SARS-CoV & Loizzo ve ark., 2008 \\
\hline Mentha piperita $\mathrm{L}$. & IBV & Lelesius ve ark., 2019 \\
\hline Nigella sativa $\mathrm{L}$. & MHV-A59 & Ulaşlı ve ark., 2014 \\
\hline Origanum vulgare L.* & CDV, EAV & Blank ve ark., 2019 \\
\hline Origanum vulgare L.* & IBV & Lelesius ve ark., 2019 \\
\hline Potentilla arguta Pursh. ${ }^{*}$ & BRSV & Ökdem, 2017 \\
\hline Potentilla arguta Pursh. ${ }^{*}$ & RSV & Kotwal ve ark., 2005 \\
\hline Rosa canina $\mathrm{C}$. & RSV & Güçlü ve Yüksel, 2017 \\
\hline Thymus vulgaris L.* & IBV & Lelesius ve ark., 2019 \\
\hline Thymus vulgaris L.* & PRRSV & Kaewprom ve ark., 2017 \\
\hline Trifolium africanum Ser.* & SARS-CoV & Kotwal ve ark., 2005 \\
\hline
\end{tabular}

*Tablo 1'de kullanımı olup; aynı cinse sahip farklı türler

BRSV: Sığır Sinsityal Solunum Virüs, CDV: Köpek Distemper Virüs, EAV: At Arterit Virüs, IBV: Kuş Bulaşıcı Bronşit Virüs, MHV-A59: Fare Hepatit Virüs, PRRSV: Domuz Üreme ve Solunum Sendromu Virüs, RSV: Solunum Sinsityal Virüs, SARS-CoV: Şiddetli Akut Solunum Yolu Sendromu Koronavirüs 
Journal of Integrative and Anatolian Medicine

Bütünleyici ve Anadolu Tıbbı Dergisi
Cilt/ Volume: 2 Sayı / Issue: 3 Yil/Year: 2021
Yayınc1 / Publisher Sağlk Bilimleri Üniversitesi University of Health Sciences

Tablo 3. Ankara İli Etnobotanik Çalışma Bölgelerine Göre,

Kullanımları Covid-19 Belirtileriyle Eşleşen Bitki Türlerinin Sayısı ve Oranı

\begin{tabular}{|c|c|c|}
\hline $\begin{array}{c}\text { Ankara İli Etnobotanik } \\
\text { Çalışma Bölgeleri }\end{array}$ & $\begin{array}{c}\text { Bitki Türü } \\
\text { Sayısı }\end{array}$ & \% Oran \\
\hline Beypazarı-Ayaş-Güdül & 10 & 15.38 \\
\hline Çamlıdere & 33 & 50.76 \\
\hline Güdül & 1 & 1.53 \\
\hline Haymana & 2 & 3.07 \\
\hline $\begin{array}{c}\text { Polatlı Avşar Köyü- } \\
\text { Şabanözü-Çile Dağı }\end{array}$ & 10 & 15.38 \\
\hline Yenimahalle-Kazan & 9 & 13.84 \\
\hline
\end{tabular}

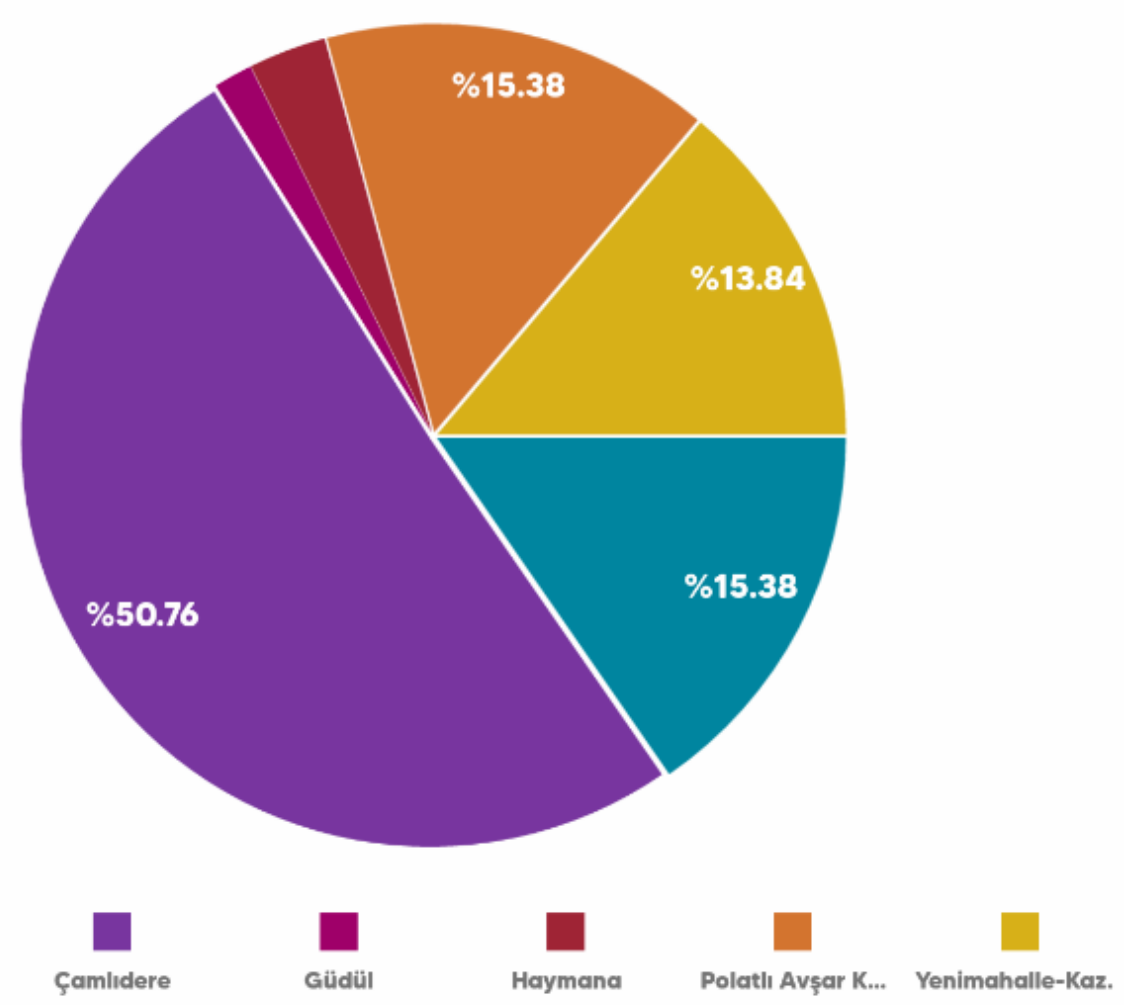

Şekil 2. Ankara İli Etnobotanik Çalışma Bölgelerine Göre; Kullanımları Covid-19 Belirtileriyle Uygunluk Gösteren Bitki Türlerinin Dağılımı 
Journal of Integrative and Anatolian Medicine

Bütünleyici ve Anadolu Tibbı Dergisi
Cilt/ Volume: 2 Sayı / Issue: 3 Yll/Year: 2021
Yayncs / Publisher

Sağlk Bilimleri Üniversitesi University of Health Sciences

Tablo 4. Kullanım Alanına Göre Bitki Türlerinin Sayısı ve Oranı

\begin{tabular}{|c|c|c|}
\hline Kullanım Alanı & Bitki Türü Sayısı & $\%$ Oran \\
\hline Akciğer hastalıkları & 1 & 1.05 \\
\hline Akciğer ödemi & 1 & 1.05 \\
\hline Astım & 6 & 6.31 \\
\hline Ateş & 3 & 3.15 \\
\hline Boğaz ağnıs1 & 1 & 1.05 \\
\hline Bronşit & 16 & 16.84 \\
\hline Ekspektoran & 4 & 4.21 \\
\hline Gargara olarak & 2 & 2.10 \\
\hline Göğüs yumuşatıcı & 1 & 1.05 \\
\hline Nefes darlığ1 & 20 & 21.05 \\
\hline Öksürük & 23 & 24.21 \\
\hline Pnömoni & 3 & 3.15 \\
\hline Soğuk algınlığ & 12 & 12.63 \\
\hline Solunum yolu hastalıkları & 2 & 2.10 \\
\hline
\end{tabular}


Journal of Integrative and Anatolian Medicine

Bütünleyici ve Anadolu Tıbbı Dergisi
Cilt/ Volume: 2 Sayı / Issue: 3 Yil/Year: 2021
Yayınc / Publisher Sağlk Bilimleri Üniversitesi University of Health Sciences
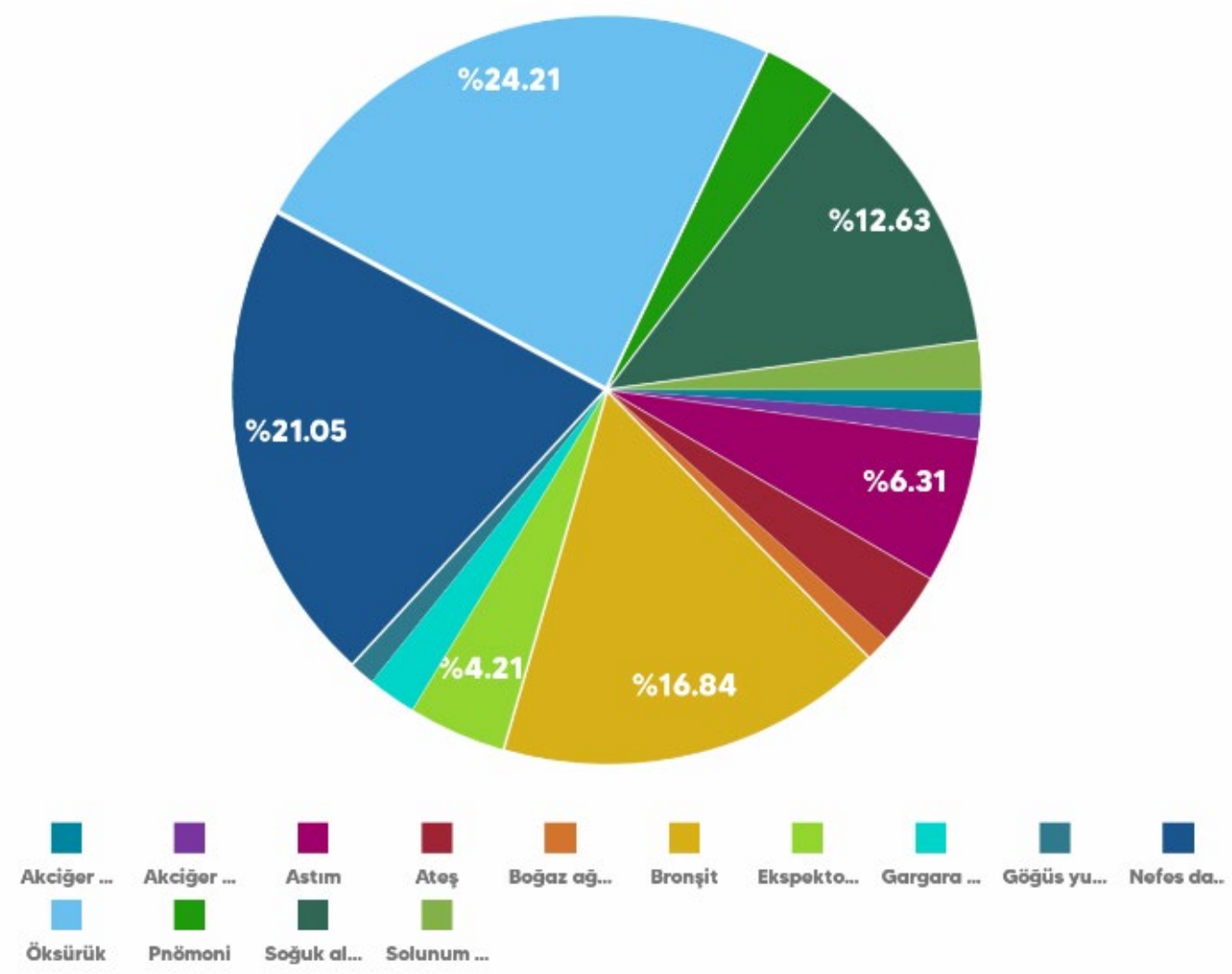

Şekil 3. Kullanım Alanına Göre Bitki Türlerinin Dağılımı

\section{SONUÇ}

Bitkiler halk arasında gıda, ilaç ya da farklı amaçlarla yüzyıllardır kullanılmaktadır. Etnobotanik çalışmalar, bitkilerin yetiştirilmesi, kullanım amaçları ve kullanım şekillerinin belirlenmesi açısından önemli olup; bitkilerin yanlış ve bilinçsiz kullanımlarını önlemekte, ayrıca devamında yapılacak bilimsel aktivite çalışmalarına da zemin hazırlamaktadır.

Türkiye'de 1928-1997 y1lları arasında, 466 bitkinin tıbbi amaçla kullanıldığ tespit edilmiştir. 1998-2008 Y1lları arasında yapılan etnobotanik çalışmalar ise, Gülsen Kendir ve Ayşegül Güvenç tarafından derlenmiş olup; Antalya, Tekirdağ, Isparta, Denizli, Zonguldak, İstanbul ve daha birçok şehri içine alan 91 etnobotanik çalışma özetlenmiştir (Kendir, 2010). Etnobotanik çalışmalar sonrasında, etkili olabileceği düşünülen bitkiler uygun çözücülerle ekstre edilir, fraksiyonlanır ya da etken maddelerin izolasyonu yapilir.

Bugün bitki ekstraktlarının ya da etkili maddelerinin yer aldığı çok sayıda müstahzar onaylanmıştır ve eczacı meslektaşlarımız tarafından satışı yapılmaktadır.

2019 yılı itibariyle, Dünya Sağlık Örgütü tarafından pandemi ilan edilen Covid-19, dünyada bütün yaşam tarzını değiştirmiş, çok sayıda ölüme neden olmuş; tıp ve eczacılık alanında da yeni viral hastalıklar, yeni virüsler ve tedavi şekilleri üzerine araştırmalara yoğunluk kazandırmıştır. RNA virüslere ve özellikle SARS-CoV-2'ye karşı sentetik ilaçlarla birlikte önlem ya da tedavi amaciyla, tamamlayıcı olarak bitkilere yönelinmiş; pek çok bitki ve doğal ürün üzerinde araştırmalar yapılmıştır. 
Journal of Integrative and Anatolian Medicine

Bütünleyici ve Anadolu Tıbbı Dergisi
Cilt/ Volume: 2 Sayı / Issue: 3

Yil/Year: 2021
Yayncs / Publisher

Sağllk Bilimleri Üniversitesi University of Health Sciences
Covid-19'da SARS-CoV-2, akut pnömoni etkenidir. $\mathrm{Bu}$ virüs ile enfekte olmuş kişilerde, ateş, grip benzeri belirtiler, öksürük, baş ağrısı, kas ağrısı, nefes darlığı yanında; kusma ve ishal gibi atipik belirtiler görülmektedir (Patel ve ark., 2020). Ankara ilinin, Altındağ-Bağlum-Kılıçlar, Beypazarı-Ayaş-Güdül, Çamlıdere, Çubuk çayıTatlar arası, Güdül, Haymana, Polatlı (AvşarŞabanözü-Çile Dağı) ve Yenimahalle-Kazan bölgelerinde yapılan etnobotanik çalışmalarda, kullanımları, Covid-19 belirtileri ile uygunluk gösteren türler Tablo 1'de verilmiştir. $\mathrm{Bu}$ bitkilerden, RNA virüslere karşı antiviral aktivite tayini sonucu etkili bulunmuş 6 tür ise Tablo 2'de verilmiş olup; bu türler, Allium sativum L., Cistus laurifolius L., Juniperus oxycedrus L. subsp. oxycedrus L., Mentha piperita L., Nigella sativa L. ve Rosa canina L. dir.

Etnobotanik çalışmalar sonucunda, kullanılışları Covid-19 belirtilerine uygunluk gösteren 24 familyadan 53 tür tespit edilmiştir. En fazla kullanım, 12 tür ile Lamiaceae familyasına ve 6 tür ile Thymus cinsine aittir. Bu türlerin kullanıldığı rahatsızlıklar, bronşit, öksürük, nefes darlığı ve soğuk algınlığıdır. 4 Thymus türü Çamlıdere'de olmak üzere, diğerleri Güdül ve Beypazarı-Ayaş-Güdül bölgelerinde yetişmektedir. Çalışılan bölgelerde Covid-19 belirtilerine karşı uygun kullanılış gösteren en fazla türe sahip familya ve cinsler; Asteraceae'den 4 tür Anthemis, Cupressaceae den 2 tür Juniperus, Lamiaceae'den 3 tür Mentha ve 6 tür Thymus, Rosaceae'den 2 tür Malus ve 3 tür Rosa, Liliaceae'den 2 tür Allium bitkisidir. Mentha türlerinden 1'i Beypazarı-Ayaş-Güdül ve 2'si Çamlıdere'de, Thymus türlerinden 4'ü Çamlıdere, 1'i Güdül ve diğeri Beypazarı-AyaşGüdül'de kullanılmaktadır. Asteracae familyasından 4 Anthemis türünün 2'si Çamlıdere ve diğer 2'si Polatlı bölgesinde yer almaktadır (Tablo 1).

En fazla kullanım öksürük kesici olarak; 23 tür ile \%24.41, diğeri ise 20 tür ile nefes darlığında kullanım olup; dağılımı \%21.05'tir (Tablo 4, Şekil 3). Çamlıdere bölgesi, 33 tür ile belirtilere uygunluk açısından en fazla kullanıma sahip bölge olup; kullanım dağılımı \%50.76'dır. 16 tür, nefes darlığında kullanılmakta olup; dağılımı \%48.48, 6 tür ise öksürükte kullanılmakta olup; dağılımı \%18.18'dir (Tablo 3, 4, Şekil 2, 3).

Tablo 2 incelendiğinde; Ankara ilinde yapılan etnobotanik çalışmada, Polatlı Şabanözü Köyü'nde yetişen Allium sativum L.'un, Beypazarı-Ayaş-Güdül, Haymana, Polatlı ve Çamlıdere'de yetişen Rosa canina C.'nın kullanım amaçları ile antiviral çalışmalarının uyumlu olduğu görülmektedir. $\mathrm{Bu}$ türlerden Origanum vulgare L., Beypazar1-Ayaş-Güdül bölgesinde yapılan etnobotanik çalışmada yer almakla birlikte; Covid-19 belirtilerine karşı uygunluk gösteren kullanılışı yoktur. Bu nedenle Tablo 1'de yer almamıştır. Ancak Doğu Karadeniz bölgesinde yapılan çalışmada, çiçeklerinin astımda infüzyon olarak kullanımı bulunmaktadır (Birinci, 2008). Yapılan antiviral çalışmada, CDV, EAV ve IBV üzerinde etkileri gösterilmiştir. Uçucu yağları bakımından zengin olan Origanum türlerinde uçucu yağ ana bileşiği karvakrol olup; diğerleri; linalol, $p$-simen, timol, mirsen ve $\gamma$-terpinendir. Karvakrolün doğal dezenfektan olarak kullanımı gösterilmiştir (Şekeroğlu ve Gezici, 2020). Ayrıca Cistus, Origanum, Rosa ve Salvia türlerinin, stres giderici Nigella sativa'nın antioksidan olarak bağışıklığı güçlendirici etkileri de bildirilmiştir (Ali, 2015; Perez, 2020).

Etnobotanik çalışmalarda kullanılışı tespit edilen bazı bitkilerle aynı cinse sahip Anthemis hyalina DC., Mentha officinalis L., Potentilla arguta Pursh, Prunus cerasus L., Origanum vulgaris L., Salvia officinalis L., Thymus vulgaris L. ve Trifolium africana Ser. gibi farklı türlerin de antiviral etki gösterdikleri görülmüştür.

Ankara ilindeki 4 farklı Anthemis türü Tablo 1'de gösterilmiştir. Tablo 1'de olmayan; ancak 
Journal of Integrative and Anatolian Medicine

Bütünleyici ve Anadolu Tıbbı Dergisi
Cilt/ Volume: 2 Sayı / Issue: 3

Yil/Year: 2021
Yayıncı / Publisher

Sağllk Bilimleri Üniversitesi University of Health Sciences yöresel adı papatya, derman olan Anthemis hyalina DC.'nın Şanlıurfa-Birecik bölgesinde yapılmış olan etnobotanik çalışmada, çiçeklerinin, astım, bronşit ve nefes darlığında kullanıldığ 1 ve bu kullanımının antiviral aktivite çalışması ile uyumlu olduğu görülmüştür (Tablo 2) (Balos ve Akan, 2007). Uçucu yağları bakımından zengin olan Asteraceae bitkilerinden Anthemis nobilis L.'in nezlede ve stres giderici olarak kullanımı olup; uçucu yağ bileşenleri, pinokarvon, farnesol, pinen, bisabolol, sineol, pinokarveol, azulen, $\beta$-karyofilen, kafur ve mirsendir. $\mathrm{Bu}$ bileşiklerden sineolün, antiseptik ve ekspektoran etkisi bulunmaktadır (Ali, 2015).

Nonterpen ve labdan tip diterpenler taşıyan bazı Cistus türlerinin ülkemizde ekspektoran olarak kullanılışları bildirilmiştir. Bu türlerden biri olan Cistus laurifolius L., PI-3 virüsü üzerinde etkili bulunmuştur. Ayrıca farklı Cistus türleri üzerinde yapılan çalışmalarda, kuş gribine ve in vivo ortamda influenza A ve B'ye karş1 etkileri gösterilmiştir (Ustun ve ark., 2016; Şekeroğlu ve Gezici, 2020).

Çamlıdere bölgesinde bronşitte, öksürük kesici, nefes darlığında, ateş düşürücü olarak kullanılışları Covid-19 belirtilerine karşı uygunluk gösteren 3 Mentha türü; Mentha x piperita L., Mentha longifolia (L.) Hudson, Mentha longifolia (L.) Huds. subsp. longifolia olarak tespit edilmiştir ve Tablo 1'de gösterilmiştir. Nefes darlığında kullanılan Mentha x piperita L.'nın IBV üzerinde etkisi de tespit edilmiştir (Lelesius ve ark., 2019). Antiviral çalışmalar, toprak üstü kısımları ile yapılmıştır. Lamiaceae familyası bitkilerinden olan Mentha türleri, uçucu yağları bakımından zengindir. Mentha x piperita L.'nın uçucu yağında \%44 mentol bulunur. Diğer bileşenler, karvakrol, karvon, metil asetat, limonen ve mentondur. Uçucu yağı antiseptik, analjezik ve antiviraldir. Mentol ise antiseptik olup; \%0.1-2 oranında kullanılmaktadır (Tyler ve ark., 1988). Zengin monoterpenleri nedeniyle farklı Mentha türlerinin solunum yolu enfeksiyonlarında kullanıldıkları da bildirilmiştir (Şekeroğlu ve Gezici, 2020).

Etnobotanik çalışmada öksürük kesici olarak kullanıldığı tespit edilen Olea europaea L.'dan elde edilen sabit yağın (zeytinyağı) etken maddesi, oleuropeindir. Oleuropein, influenza etkilerini azaltıcı olarak kullanılmaktadır (Şekeroğlu ve Gezici, 2020).

Ankara'da gösterilmemekle birlikte, Adıyaman-Kahta'da yapılan etnobotanik çalışmada tespit edilen ve bölgede adaçayı, deve dili, acı elma otu olarak bilinen Salvia officinalis L.'in, mikrop öldürücü etkiye sahip olduğu, toprak üstü kısımlarının soğuk algınlığ 1 ve boğaz enfeksiyonlarında kullanıldığı görülmüştür (Akan ve Sade, 2015). Uçucu yağ ve bileşikleri yönünden de zengin olan bitki, antiseptik olarak da kullanılmaktadır. Uçucu yağ bileşiklerinden başlicalar1; borneol, kafur, 1,8-sineol, kamfen, limonen, $\alpha$-pinen, $\beta$-pinen, $\alpha$-tuyon, $\beta$-tuyon, $\alpha$ humulen ve $\beta$-karyofilendir (Şekeroğlu ve Gezici, 2020). Meyvelerinin uçucu yağı üzerinde yapılan antiviral çalışmalarda, SARS-CoV üzerinde etkili bulunmuştur (Loizzo ve ark., 2008). Toprak üstü kısımlarının IBV üzerinde etkisi görülmüştür (Lelesius ve ark., 2019).

Ankara ili etnobotanik çalışmalarında tespit edilmemiş olmakla birlikte; Uşak ilinde yapılan çalışmada Potentilla recta L.'nın boğaz hastalıklarında kullanıldığı bildirilmiştir (Deniz ve ark., 2010). Ayrica Potentilla arguta Pursh.'nın RSV ve BRSV üzerinde antiviral etkisi gösterilmiştir (Kotwal ve ark., 2005; Ökdem, 2017).

Trifolium fragiferum L. var. fragiferum Çamlıdere'de, Trifolium campestree Schreb. Polatl1-Avşar Köyü-Çile Dağı'nda ve Trifolium phleoides Pourr ex Willd. Beypazar1-AyaşGüdül'de yetişmekte olup; etnobotanik çalışmalarında farklı kullanılışları bulunmaktadır. $\mathrm{Bu}$ nedenle Tablo 1'de gösterilmemiştir. Trifolium pratense L.'nin 
Journal of Integrative and Anatolian Medicine

Bütünleyici ve Anadolu Tıbbı Dergisi
Cilt/ Volume: 2 Sayı / Issue: 3

Yil/Year: 2021
Yayncs / Publisher

Sağllk Bilimleri Üniversitesi University of Health Sciences yapraklarının uçucu yağ bileşenleri bakımından zengin olduğu bilinmektedir (Renda, 2010).

Ankara ili etnobotanik çalışmalarında Beypazarı-Ayaş-Güdül'de Thymus leucostomus Hausskn. \& Velen. ssp. leucostomus, Çamlıdere'de Thymus leucotrichus Halácsy var. leucotrichus, Thymus longicaulis C.Presl subsp. longicaulis var. longicaulis, Thymus longicaulis C. Presl. subsp. longicaulis var. subisophyllus (Borbas) Jalas, Thymus praecox Opiz subsp. skorpilii (Velen.) Jalas var. skorpilii, Güdül'de Thymus longicaulis C. Presl. türlerinin nefes darlığı, öksürük, bronşit, soğuk algınlığında ve ekspektoran olarak kullanıldıkları Tablo 1'de gösterilmiştir. IBV ve PRRSV'ye etkisi gösterilen Thymus vulgaris L.'in, Ankara ilinde etnobotanik çalışması yoktur. Ancak TokatReşadiye'de yapılan etnobotanik çalışmada, bitkinin soğuk algınlığ 1 , göğüs yumuşatıcı olarak ve nefes darlığında kullanıldı̆̆ (Yüzbaşığlu, 2010). Uçucu yağ bakımından zengin olan türün \%36-55'ini timol oluşturmaktadır. Önemli diğer maddeleri ise; \%15-28 $p$-simen, \%5-10 terpinen, \%1-4 karvakrol, $\beta$-karyofilen, \%4-6.5 linalol, \%1-3 mirsen, \%0.2-4 terpin-4-ol; ayrica tujen, pinen, kafur, 1,8-sineol, borneol, humulen, kopen, kubeben, gurjunen, germakren $\mathrm{D}$, murolen ve kadinendir (Bozdemir, 2019).

\section{TARTIŞMA}

Covid-19 pandemisiyle birlikte, bitkilerin kullanımı ve antiviral aktivite çalışmalarında artış görülmüştür. Antiviral tedavinin amac1, hastalığın belirtilerini ve bulaşıcılık seviyesini azaltmak, tedavi süresini kısaltmaktır. Bugün, dirençli suşlar ve yeni mutantlar nedeniyle, yeni antiviral etkili maddelere ihtiyaç duyulmaktadır. Bitkiler halk ilacı olarak birçok hastalığın tedavisinde kullanılmaktadır. Etnobotanik çalışmalar, bitkilerin, halk arasındaki kullanılışları hakkında bilgi vermekte; ekstraktlar, fraksiyonlar ya da etken maddeler üzerinde yapılacak aktivite tayini çalışmalarında yol göstermektedir. Covid-19 pandemisinin yaşandığ ve yeni ilaç arayışlarına girildiği günümüzde, SARS-CoV-2 ile enfekte hastalarda belirtileri azaltmak, bitkileri tıbbi tedaviye dahil edebilmek amaciyla bu derleme çalışması yapılmıştır.

Tablo 2'de gösterilen türlerden Origanum vulgare L.'nin RNA viriüsler üzerinde antiviral etkisinin tespiti ve etnobotanik çalışmada Polatlı Avşar Köyü-Çile Dağı'nda solunum yolu hastalıklarında kullanılan Origanum sipyleum L.'un da antiviral çalışmaların yapılması önerilmektedir. Nefes darlığında kullanılışı tespit edilmiş olan ve Polatlı Avşar Köyü-Çile Dağı, Çamlıdere ile Yenimahalle-Kazan' da kullanılan Juniperus oxycedrus L. subsp. oxycedrus L.'un antiviral çalışmada SARS-CoV üzerinde etkisi gösterilirken; etnobotanik çalışmada Çamlıdere'de yetişen Juniperus oxycedrus L.'un da nefes darlığında kullanıldığı görülmektedir. $\mathrm{Bu}$ türün de SARS-CoV'a etkisinin çalışması yararlı olacaktır. IBV'ye etkisi tespit edilen ve etnobotanik çalışmada Polatlı Avşar Köyü-Çile Dağı'nda yetişen, nefes darlığında halk arasında kullanılan Mentha piperita L.ye karşın, yine bronşitte kullanıldığı tespit edilen ve BeypazarıAyaş-Güdül bölgesinde yetişen Mentha longifolia (L.) Hudson üzerinde de antiviral çalışmalar yapılmalıdır. Ayrıca antiviral etileri tespit edilmiş olan Tablo 2'deki 6 türün, Covid19 pandemisi üzerinde değerlendirilip; SARSCoV-2 üzerinde etkilerinin araştırılması önerilmektedir.

SARS-CoV'a etkisi tespit edilen Trifolium africana Ser. nedeniyle, Trifolium türlerinin uçucu yağları ve etkili bileşiklerinin SARS-CoV2'ye etkileri araştırılmalıdır. Salvia officinalis L.'in uçucu yağlarının, SARS-CoV'a etkisi nedeniyle, Çubuk-Tatlar, Güdül ve Polatlı bölgelerinde etnobotanik çalışmaları yapılmış olan; ancak tıbbi kullanımı tespit edilmemiş Salvia türlerinin de uçucu yağları üzerinde 
antiviral aktivite çalışmalarına yoğunlaşılması faydalı olacaktır. Potentilla arguta Pursh.'nın antiviral etkisinin tespit edilmiş olması nedeniyle, Potentilla recta L.'nın da antiviral aktivite bakımından araştırılması yararlı olacaktır. Prunus cerasus L.'un PEDV üzerinde antiviral etkisinin tespit edilmiş olması nedeniyle; Ankara ili Çamlıdere bölgesinde soğuk algınlığı ve öksürükte kullanıldığı görülen Prunus spinosa L. subsp. dasyphylla (Schur) Domin'nın, aynı cinse ait tür olması bakımından RNA virüsleri üzerine etkileri araştırılmalıdır.

Uçucu yağlar, en az yan etkilere sahip olup; güvenilir bileşiklere sahiptir. Tamamlayıcı ve alternatif tıpta kullanılabilmeleri mümkündür. (Ali, 2015). Nezle, soğuk algınlığı ve hapşırıkta kullanımları, nefes açıc1, öksürük kesici, bağışıklığ 1 güçlendirici, stres giderici, antiviral ve hava temizleyici etkileri bilinmektedir (Perez, 2020). Uçucu yağlar, lipofilik özellikleri nedeniyle viral membranlara kolayca nüfuz ettiğinden ve membranların bozulmasına neden olduğundan, SARS-CoV-2 için tavsiye edilmektedir. Pandemide, uçucu yağ ve etkili bileşikleri yönünden zengin olan Thymus (Kekik) başta olmak üzere, pek çok bitkinin bilinçsiz kullanıldığı görülmüştür. Ancak bilimsel araştırma yapılmadan uçucu yağların doğrudan insan üzerinde kullanılması doğru değildir. Thymus uçucu yağının, zarflı virüslerin lipit zarfları ile etkileşime girerek; bu zarfı yok ettiği gösterilmiştir. Öjenol, timol ve karvakrol, bu etkiden sorumlu bileşiklerdir (Reichling, 2020; Şekeroğlu ve Gezici, 2020). Thymus vulgaris L.'in, uçucu yağ bileşikleri olan timol, karvakrol, $p$-simen, kamfen ve limonenden dolayı antiseptik özelliği de bilinmektedir ve dezenfektan olarak alternatif olabilir (Tyler ve ark., 1988). Thymus gibi karvakrol ve Pinus ile Mentha gibi mentol taşıyan türlerin de aynı şekilde değerlendirilmesi, uçucu yağlar yönünden zengin olan Anthemis, Cistus, Juniperus, Mentha, Origanum, Pinus, Rosa, Salvia, Thymus ve Trifolium türleri üzerinde bilimsel aktivite çalışmalarının yapılarak; uçucu yağlarının ve etkili bileşiklerinin, Covid-19 pandemisinde değerlendirilmesi önerilmektedir. Oleuropein ve kersetin fenolik bileşiklerinin koronavirüs tedavisinde ümit vadetmesi nedeniyle; Olea europaea L. ve Allium cepa L. türlerinin, ayrıca bağışıklığı güçlendirici etkileri bakımından Cistus, Origanum, Rosa ve Salvia türlerinin değerlendirilmesi faydalı olacaktır. Covid-19 belirtilerine karşı kullanımları uygunluk gösteren Tablo 1 bitkilerinin, SARS-CoV-2 üzerine de etkilerinin çalışılarak; tıbbi kullanıma dahil edilmeleri, yeni ilaç çalışmalarının arttığ 1 Covid19 pandemisi açısından önem taşımaktadır. Sonuçları araştırmak üzere, bir ekip oluşturularak; proje yapılması planlanmaktadır.

\section{KAYNAKLAR}

Aanouz, I., Belhassana, A., El-Khatabia, K., Lakhlifia, T., El-ldrissia, M. ve Bouachrinea, M. (2021). Moroccan medicinal plants as inhibitors against SARS-CoV-2 main protease: Computational investigations. Journal of Biomolecular Structure and Dynamics, 39, 2971-2979. doi:10.1080/07391102.2020.1758790.

Akan, H ve Sade, Y.B. (2015). Kâhta (Adiyaman) Merkezi ve Narince Köyü'nün etnobotanik açıdan araştırılması. Bitlis Eren Üniversitesi Fen Bilimleri Dergisi, 4, 219-248. doi.org/10.17798/beufen.47724.

Akdağ, E. (2019). Çubuk Çayı- Tatlar arasında kalan bölgenin florası ve etnobotanik özelliklerinin araştırılması (Yüksek lisans tezi, Fen Bilimleri Enstitüsü, Ankara Üniversitesi, Ankara).

Ali, B., Al-Wabel, N.A., Shams, S., Ahamad, A., Khan, S.A. ve Anwar, F. (2015). Essential oils used in aromatherapy: A systemic review. Asian Pasific Journal of Tropical Biomedicine, 5, 589-598. doi: 10.1016/j.apjtb.2015.05.007

Ayandın, H. (2010). Avşar, Şabanözü ve Çile Dağı (Polatlı/Ankara) arasında kalan bölgenin etnobotanik özellikleri (Yüksek lisans tezi, Selçuk Üniversitesi, Fen Bilimleri Enstitüsü, Konya). 
Journal of Integrative and Anatolian Medicine

Bütünleyici ve Anadolu Tıbbı Dergisi
Cilt/ Volume: 2 Sayı / Issue: 3 Yll/Year: 2021
Yayıncı / Publisher

Sağllk Bilimleri Üniversitesi University of Health Sciences
Balos, M.M ve Akan, H. (2007). Zeytinbahçe-Akarçay (Birecik-Şanlıurfa) arasında kalan bölgenin etnobotanik özellikleri. Selçuk Üniversitesi Fen Edebiyat Fakültesi Fen Dergisi, 29, 155-171.

Batiha, G.E., Beshbishy, A.M., Wasef, L.G., Elewa, Y.H.A., Al-Sagan, A.A., Abd El Hack, M.E....Devkota, H.P. (2020).Chemical constituents and pharmacological activities of Garlic (Allium sativum L.): A Review. Nutrients, 12, 872-893. doi:10.3390/nu 12030872.

Birinci, S., (2008). Doğu Karadeniz bölgesinde doğal olarak bulunan faydalı bitkiler ve kullanım alanlarının araștırılması (Yüksek lisans tezi, Fen Bilimleri Enstitüsü, Çukurova Üniversitesi, Adana).

Blank, D.E., Hübner, S.O., Alves, G.H., Cardoso, C.A.L., Freitag, R.A. ve Cleff, M.B. (2019). Chemical composition and antiviral effect of extracts of Origanum vulgare. Advances in Bioscience and Biotechnology, 10, doi:10.4236/abb.2019.107014.

Bozdemir, Ç. (2019). Türkiye'de yetişen kekik türleri, ekonomik önemi ve kullanım alanları. Yüzüncü Yll Üniversitesi Tarım Bilimleri Dergisi, 29.

CDC (2020), Novel Coronavirus (2019). Wuhan, China. Erişim adresi (1-15 Temmuz 2020): http://www.cdc.gov

Cyranoski, D. (2020). Asya Pasifik, Profile of a killer: the complex biology powering the coronavirus pandemic. Nature.

Deniz, L., Serteser, A. ve Kargıŏlu, M. (2010). Uşak Üniversitesi ve yakın çevresindeki bazı bitkilerin mahalli adları ve etnobotanik özellikleri. Afyon Kocatepe Üniversitesi Fen Bilimleri Dergisi, 1, 57-72.

Elçi, B. ve Erik, S. (2006). Güdül Ankara ve çevresinin etnobotanik özellikleri. Hacettepe Üniversitesi Eczacılık Fakültesi Dergisi, 26, 57-64.

Fehr, A.R. ve Perlman, S. Coronaviruses: An overview of their replication and pathogenesis (Chapter 1). Maier et al (eds.), Coronaviruses: Methods and protocols, Methods in Moleculer Biology, 1282, 1-23, New York 2015. doi:10.1007/978-1-49392438-7-1

Geller, C., Varbanov, M. ve Duval, R.E. (2012). Human coronaviruses: insights into environmental resistance and its influence on the development of new antiseptic strategies. Viruses, 4, 3044-3068. doi:10.3390/v4113044.

Graham, R.L. ve Baric, R.S. (2020). SARS-CoV-2: Combating Coronavirus emergence. Journal preproof, 52, 734-736. doi: 10.1016/j.immuni.2020.04.016.

Groneberg, D.A., Hilgenfeld, R. ve Zabel, P. (2005). Molecular mechanisms of severe acute respiratory syndrome (SARS). Respiratory Research, 6, 1-16. doi:10.1186/1465-9921-6-8.

Güçlü, İ. ve Yüksel, V. (2017). Fitoterapide antiviral bitkiler. Deneysel Tıp Araştırma Enstitüsü Dergisi, 7, 25-34.

Günbatan, T., Gürbüz, İ ve Özkan, A.M.G (2016). The current status of ethnopharmacobotanical knowledge in Çamlıdere (Ankara, Turkey). Turkish Journal of Botany, 40, 241-249. doi:10.3906/bot-1501-37

İlbay, S. Toplum kaynaklı solunum yolu koronavirüsleri (Community-acquired respiratory coronaviruses, CAR-CoV). Erişim adresi (21 Mart 2021): http://www.cocukenfeksiyondernegi.org/upload/ MevsimselKoronavirusler.pdf

Kaewprom, K., Chen, Y., Lin, C., Chiou, M. ve Lin, C. (2017). Antiviral activity of Thymus vulgaris and Nepeta cataria hydrosols against porcine reproductive and respiratory syndrome virus. Phai Journal of Veterinary Medicine, 47, 25-33.

Kaya, A. (2011). Tıbbi bitkiler ve etnobotanik çalışmalar. M.D. Çekin ve diğerleri (Ed.), Bitkilerle Tedavi (s.11-18) içinde. Türkiye: İklim Ofset.

Kendir, G. ve Güvenç, A. (2010). Etnobotanik ve Türkiye'de yapılmış etnobotanik çalışmalara genel bir bakış. Hacettepe Üniversitesi Eczacılık Fakültesi Dergisi, 30, 49-80.

Kotwal, G.J., Kaczmarek, J.N., Leivers, S., Ghebremariam, Y.T., Kulkarni, A.P., Bauer, G......Mohamed, A.R. (2005). Anti-HIV, anti-poxvirus, and antiSARS activity of a nontoxic, acidic plant extract from the Trifolium species Secomet-V/anti-vac suggests that it contains a novel broad-spectrum antiviral. Annals of the New York Academy of Sciences, 1056, 293-302. doi:10.1196/annals.1352.014. 
Lans, C., Turner, N., Khan, T., Brauer, G. ve Boepple, W. (2007). Ethnoveterinary medicines used for ruminants in British Columbia, Canada. Journal of Ethnobiology and Ethnomedicine, 3, 1-22. doi: 10.1186/1746-4269-3-11.

Lelesius, R., Karpovaite, A., Mickiene, R., Drevinskas, T., Tiso, N., Ragazinskiene. O...Solomskas, A. (2019). In vitro antiviral activity of fifteen plant extracts against avian infectious bronchitis virüs. BMC Veterinary Research, 15, 178-188. doi:10.1186/s12917-019-1925-6.

Li, S., Chen,C., Zhang, H., Guo, H., Wang, H., Wang, L., Zhang, X., Hua, S., Yu, J., Xiao, P., Li, R. ve Tan, X. (2020). Identification of natural compounds with antiviral activities against SARS-associated coronavirus. PubMed Central, 1-11.

Loizzo, M.R., Saabb, A.M., Tundisa, R., Stattia, G.A., Menichinia, F., Lamprontic, I.....Doerre, H.W. (2008). Phytochemical analysis and in vitro antiviral activities of the essential oils of seven Lebanon species. Chemistry \& Biodiversity, 5, 461-470. doi:10.1002/cbdv.200890045

Mani, J.S., Johnson, J.B., Steel, J.C., Broszczak, D.A., Neilsen, P.M., Walsh, K.B. ve Naiker, M. (2020). Natural product-derived phytochemicals as potential agents against coronaviruses: A review, Virus Research, 15, 1-34. doi:10.1016/j.viruses.2020.197989.

Mehrbud, P., Amini, E. ve Tavassoti-Kheiri, M. (2009). Antiviral activity of garlic extract on influenza virus, Iranian Journal of Virology, 3, 19-23.

Ökdem, B. (2017). Potentilla recta L. bitkisi üzerinde farmakognozik araştırmalar. (Doktora tez, Sağlık Bilimleri Enstitüsü, Erciyes Üniversitesi, Kayseri).

Robbins, W.W., Harrington, J.P. ve Freire-Marreco, B. (1916). Ethnobotany of the Tewa Indians. Smithsonian Institution Bureau of American Ethnology Bulletin, 55, 1-124.

Patel, S.K.S., Lee, J. ve Kalia, V.C. (2020). Deploying biomolecules as anti-COVID-19 agents. Indian Journal of Microbiology, 60, 263-268. doi:10.1007/s12088-020-00893-4.

Perez, N. (2020). Essential oils, coronavirus \& covid19. International Federation of Aromatherapists. Erişim adresi (18.06.2021):
https://ifaroma.org/en_GB/home/blog/essentialoils-coronavirus-covid 19

Reichling, J. (2020). How SARS-CoV-2 enters human cells $\&$ essential oils. International Federation of Aromatherapists. Erişim adresi (18 Haziran 2021): https://ifaroma.org/en_GB/home/blog/understand ing-the-science-how-covid-enters-human-cells

Renda, G. (2010). Bazı Trifoliıum L. türleri Üzerinde Farmakognozik Araştırmalar (Yüksek lisans tezi, Sağlık Bilimleri Enstitüsü, Hacettepe Üniversitesi Ankara).

Sarper, F., Akaydın, G., Şimşek, I. ve Yeşilada, E. (2009). An ethnobotanical field survey in the Haymana district of Ankara province in Turkey. Turkish Journal of Biology, 33, 79-88. doi:10.3906/biy0808-28.

Sezik, E., Yeşilada, E., Honda, G., Takaishi, Y., Takeda, Y. ve Tanaka, Y. (2001). Traditional medicine in Turkey $X$. folk medicine in central Anatolia. Journal of Ethnopharmacology, 75, 95-115. doi: 10.1016/s0378-8741(00)00399-8

Strephonsays.com. Alpha, beta, gama ve delta coronavirus arasındaki fark. Erişim adresi (20 Mart 2021): https://tr.strephonsays.com/alpha-beta-gammaand-delta-coronavirus-14851

Şekeroğlu, N. ve Gezici, S. (2020). Koronavirüs pandemisi ve Türkiye'nin bazı şifalı bitkileri. Anadolu Kliniği Tip Bilimleri Dergisi, 25, 163-182. doi: 10.21673/anadoluklin.72421

Şimşek, I., Aytekin, F., Yeşilada, E. ve Yıldırım, Ş. (2004). An ethnobotanical survey of the Beypazar1, Ayas and Güdül district towns of Ankara province (Turkey). Economic Botany, 58, 705-720. doi:10.1663/00130001(2004)058\%5B0705:AES OTB\%5D2.0.CO;2

The New York Times (2020). How bad will the coronavirus outbreak get? Erişim adresi (1-15 Temmuz 2020): http://www.nytimes.com/interactive/2020/world/ asia/china-coronavirus contain.html

Tyler, V.E., Brady, L.R. ve Robbers, J. (1988). Volatile oils. Pharmacognosy (s.103-135) içinde U.S.A.Lea \& Febiger.

Ulaşlı, M., Gürses, S.A., Bayraktar, R., Yumrutas, Ö., Öztuzcu, S., Iğci, M....A.Arslan, A. (2014). The effects of Nigella sativa (Ns), Anthemis hyalina (Ah) and Citrus sinensis (Cs) extracts on the 
Journal of Integrative and Anatolian Medicine

Bütünleyici ve Anadolu Tıbbı Dergisi
Cilt/ Volume: 2 Sayı / Issue: 3 Yil/Year: 2021
Yayınc / Publisher

Sağlk Bilimleri Üniversitesi University of Health Sciences replication of coronavirus and the expression of TRP genes family. Molecular Biology Reports, 41, 1703-1711. doi:10.1007/s11033-014-3019-7.

Ustun, O., Ozcelik, B ve Baykal, T. (2016). Bioactivities of ethanolic extract and its fractions of Cistus laurifolius L. (Cistaceae) and Salvia wiedemannii Boiss. (Lamiaceae) species. Pharmacognosy Magazine, 12, 82-85. doi: 10.4103/09731296.176125

Wertheim J.O., Chu D.K., Peiris J.S., Pond S.L.K. ve Poon L.L. (2013). A case for the ancient origin of coronaviruses. Journal of Virology, 87, 70397045. doi:10.1128/JVI.03273-12.

WHO. (2003). Summary table of SARS cases by country, 1 Kasım 2002-7 Ağustos2003 Erişim adresi (1-15 Temmuz 2020): http://web.archive.org/web/20131028210538/http ://www.who.int/csr/sars/country/2003_08_15/en/i ndex.html

WHO. (2017). Middle East respiratory syndrome coronavirus (MERS-CoV). Erişim adresi (1-15 Temmuz 2020): https://www.sciencedirect.com/topics/medicineand-dentistry/middle-east-respiratory-syndromecoronavirus
Woo, P.C., Lau, S.K., Lam, C.S., Lau, C.C., Tsang, A.K., Lau, J.H.....Yuen, K.Y. (2012). Discovery of seven novel Mammalian and avian coronaviruses in the genus deltacoronavirus supports bat coronaviruses as the gene source of alphacoronavirus and betacoronavirus and avian coronaviruses as the gene source of gammacoronavirus and deltacoronavirus. Journal of Virology, 86, 3995-4008. doi: 10.1128/JVI.06540-11.

Worldometers (2021). Covid-19 Coronavirus pandemic, last updated. Erişim adresi (17 Mart 2021): https://www.worldometers.info/coronavirus/

Yook, H., Kim, K., Park, J. ve Shin, H. (2010). Antioxidative and antiviral properties of flowering cherry fruits (Prunus serrulata L. var. spontanea). The American Journal of Chinese Medicine, 38, 937-948. doi:10.1142/S0192415X10008366.

Yuen, K., Ye, Z., Fung, S., Chan, C. ve Jin, D. (2020). SARS-CoV-2 and COVID-19: The most important research questions. Cell \& Bioscience, 10, 1-5. doi: 10.1186/s13578-020-00404-4.

Yüzbaşıŏlu, E. (2010). Reşadiye (A6, Tokat, Türkiye) ve çevresinin etnobotaniği (Yüksek lisans tezi, Fen Bilimleri Enstitüsü, Çanakkale Onsekiz Mart Üniversitesi, Çanakkale). 